\title{
Proteomics and bioinformatics analysis reveal potential roles of cadmium-binding proteins in cadmium tolerance and accumulation of Enterobacter cloacae
}

\author{
Kitipong Chuanboon ${ }^{1,2}$, Piyada Na Nakorn ${ }^{3}$, Supitcha Pannengpetch ${ }^{2}$, Vishuda Laengsri ${ }^{2}$, Pornlada Nuchnoi ${ }^{2}$, \\ Chartchalerm Isarankura-Na-Ayudhya ${ }^{3}$, Patcharee Isarankura-Na-Ayudhya ${ }^{\text {Corresp. } 1}$ \\ ${ }^{1}$ Department of Medical Technology, Faculty of Allied Health Science, Thammasat University, Pathumthani, Thailand \\ Center for Research and Innovation, Faculty of Medical Technology, Mahidol University, Bangkok, Thailand \\ 3 Department of Clinical Microbiology and Applied Technology, Faculty of Medical Technology, Mahidol University, Bangkok, Thailand \\ Corresponding Author: Patcharee Isarankura-Na-Ayudhya \\ Email address: pujonoy@hotmail.com
}

\section{Background}

Enterobacter cloacae (EC) is a Gram negative bacterium that has extensively been utilized in biotechnological and environmental science applications, possibly resulted from the high capability to adapt itself and survive in hazardous conditions. Searching for the EC from agricultural and industrial areas that possesses high capability to tolerate and/or accumulate cadmium ions has been conducted in this study. Plausible mechanisms of cellular adaptations in the presence of toxic cadmium have also been proposed.

\section{Methods}

Nine strains of EC were isolated and subsequently identified by biochemical characterization and MALDIBiotyper. Minimum inhibitory concentrations (MICs) against cadmium, zinc and copper ions were determined by agar dilution method. Growth tolerance against cadmium ions was spectrophotometrically monitored at $600 \mathrm{~nm}$. Cadmium accumulation at both cellular and protein levels was investigated using atomic absorption spectrophotometer. Proteomics analysis by 2D-DIGE in conjunction with protein identification by QTOF-LC-MS/MS was used to study differentially expressed proteins between the tolerant and intolerant strains as consequences of cadmium exposure. Expression of such proteins was confirmed by quantitative reverse transcription-polymerase chain reaction (qRT-PCR). Bioinformatics tools were applied to propose the functional roles of cadmium-binding protein and its association in cadmium tolerance mechanisms.

\section{Results}

The cadmium-tolerant strain (EC01) and intolerant strain (EC07) with the MICs of 1.6 and $0.4 \mathrm{mM}$, respectively, were isolated. The whole cell lysate of EC01 exhibited approximately 2 fold higher in cadmium binding capability than those of the EC07 and ATCC 13047, possibly by the expression of Cdbinding proteins. Our proteomics analysis revealed the higher expression of DUF326-like domain (a high cysteine-rich protein) of upto 220 fold in the EC01 than that of the EC07. Confirmation of the transcription level of this gene by qRT-PCR revealed 14 fold induction in the EC01. Regulation of the DUF326-like domain in EC01 was more pronounced to mediate rapid cadmium accumulation (in 6 hours) and tolerance than the other resistance mechanisms found in the ATCC 13047 and the EC07 strains. The

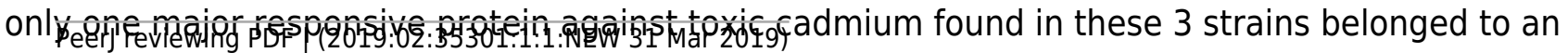


antioxidative enzyme, namely catalase. While, the unique proteins found in the ATCC 13047 and EC07 were identified as two groups: i) ATP synthase subunit alpha, putative hydrolase and superoxide dismutase and ii) OmpX, protein YciF, OmpC porin, DNA protection during starvation protein, and TrpR binding protein WrbA, respectively.

\section{Conclusion}

All these findings gain insights not only into the molecular mechanisms of cadmium tolerance in EC but also open up a high feasibility to apply the newly discovered DUF326-like domain as cadmium biosorbents for environmental remediation in the future. 
1 Proteomics and bioinformatics analysis reveal potential roles of 2 cadmium-binding proteins in cadmium tolerance and accumulation of 3 Enterobacter cloacae

4

5

Kitipong Chuanboon ${ }^{1,2}$, Piyada Na Nakorn ${ }^{3}$, Supitcha Pannengpetch ${ }^{2}$, Vishuda Laengsri ${ }^{2}$, Pornlada Nuchnoi ${ }^{2}$, Chartchalerm Isarankura-Na-Ayudhya ${ }^{3}$, Patcharee Isarankura-NaAyudhya ${ }^{1, *}$

${ }^{1}$ Department of Medical Technology, Faculty of Allied Health Science, Thammasat University, Pathumthani 12120, Thailand

${ }^{2}$ Center for Research and Innovation, Faculty of Medical Technology, Mahidol University, Bangkok 10700, Thailand

${ }^{3}$ Department of Clinical Microbiology and Applied Technology, Faculty of Medical Technology, Mahidol University, Bangkok 10700, Thailand

\section{Corresponding Author:}

Patcharee Isarankura-Na-Ayudhya ${ }^{1}$

99 Moo 18 Paholyothin Road, Klong Nueng, Klong Luang, Pathumthani 12121 Thailand Email address: pujonoy@hotmail.com

\section{Abstract}

\section{Background}

Enterobacter cloacae (EC) is a Gram negative bacterium that has extensively been utilized in biotechnological and environmental science applications, possibly resulted from the high capability to adapt itself and survive in hazardous conditions. Searching for the EC from agricultural and industrial areas that possesses high capability to tolerate and/or accumulate cadmium ions has been conducted in this study. Plausible mechanisms of cellular adaptations in the presence of toxic cadmium have also been proposed.

\section{Methods}

Nine strains of EC were isolated and subsequently identified by biochemical characterization and MALDI-Biotyper. Minimum inhibitory concentrations (MICs) against cadmium, zinc and copper ions were determined by agar dilution method. Growth tolerance against cadmium ions was spectrophotometrically monitored at $600 \mathrm{~nm}$. Cadmium accumulation at both cellular and protein levels was investigated using atomic absorption spectrophotometer. Proteomics analysis by 2DDIGE in conjunction with protein identification by QTOF-LC-MS/MS was used to study differentially expressed proteins between the tolerant and intolerant strains as consequences of cadmium exposure. Expression of such proteins was confirmed by quantitative reverse transcription-polymerase chain reaction (qRT-PCR). Bioinformatics tools were applied to 
40 propose the functional roles of cadmium-binding protein and its association in cadmium

41 tolerance mechanisms.

42 Results

43 The cadmium-tolerant strain (EC01) and intolerant strain (EC07) with the MICs of 1.6 and 0.4

$44 \mathrm{mM}$, respectively, were isolated. The whole cell lysate of EC01 exhibited approximately 2 fold

45 higher in cadmium binding capability than those of the EC07 and ATCC 13047, possibly by the

46 expression of Cd-binding proteins. Our proteomics analysis revealed the higher expression of

47 DUF326-like domain (a high cysteine-rich protein) of upto 220 fold in the EC01 than that of the

48 EC07. Confirmation of the transcription level of this gene by qRT-PCR revealed 14 fold

49 induction in the EC01. Regulation of the DUF326-like domain in EC01 was more pronounced to

50 mediate rapid cadmium accumulation (in 6 hours) and tolerance than the other resistance

51 mechanisms found in the ATCC 13047 and the EC07 strains. The only one major responsive

52 protein against toxic cadmium found in these 3 strains belonged to an antioxidative enzyme,

53 namely catalase. While, the unique proteins found in the ATCC 13047 and EC07 were identified

54 as two groups: i) ATP synthase subunit alpha, putative hydrolase and superoxide dismutase and

55 ii) OmpX, protein YciF, OmpC porin, DNA protection during starvation protein, and TrpR

56 binding protein $\mathrm{WrbA}$, respectively.

57 Conclusion

58 All these findings gain insights not only into the molecular mechanisms of cadmium tolerance in

59 EC but also open up a high feasibility to apply the newly discovered DUF326-like domain as

60 cadmium biosorbents for environmental remediation in the future.

61

\section{Introduction}

63

64

65

66

67

68

69

70

Environmental contamination by toxic heavy metals has increased dramatically due to the consequence of global industrialization. Cadmium is one kind of heavy metals that exerts its detrimental toxicity to human, animals, plants and microorganisms (Jaiswal et al. 2018). Cellular adaptation of bacteria to survive under cadmium exposure can be accounted as follows: reduction of cadmium uptake, cadmium sequestration or complexation, cadmium efflux, and secretion of extracellular polysaccharides (Nies 1992; Nies 1999; Xu et al. 2017). Among the other environmental bacteria, Enterobacter cloacae (EC), a Gram-negative bacillus belonging to the family of Enterobacteriaceae, can localize in gut and in various environmental conditions. The EC has been reported to tolerate against many kinds of heavy metals and antibiotics. For instances, the standard strain of EC (ATCC 13047) has been found to carry many heavy-metal resistance genes belonging to 7 operons (sil, ars, mer and cop) (Ren et al. 2010). Moreover, overexpression of extracellular biological components (e.g. exopolysaccharide) has been found to play major roles in chromate resistance by preventing the permeability of chromate into the cells (Iyer et al. 2004; Yang et al. 2007). Some strain of EC that confered lead resistance has been discovered to have increased production of exopolysaccharide (Naik et al. 2012). Accumulation of nickel and vanadium as well as the association between vanadium and 
80 tolerance (sil operon involved in acquired silver resistance) and antibiotic resistance (blaCTX-M 81 and blaKPC acquired extended-spectrum cephalosporin and carbapenem resistance) genes has 82 recently been documented in EC complex (Andrade et al. 2018). With respect to the high

83 tolerance and/or accumulation of metal ions, the EC has been used in many biotechnological and 84 environmental science applications such as biohydrogen production (Khanna et al. 2011), heavy 85 metal bioremediation (Rahman et al. 2015; Xu et al. 2017), nanoparticles-based 86 biotransformation, biocatalyst for decolourization of azo dye (Prasad \& Aikat 2014). Redox 87 transformation of toxic selenium oxyanions by the twin arginine translocation system has been 88 discovered (Ma et al. 2007). However, it is noteworthy that the resistance mechanisms against 89 toxic cadmium ions in Enterobacter cloacae remain unclear.

Domains of unknown/uncharacterized function (DUFs) have been recognized as a series of uncharacterized protein families, which can be accessed through the international database namely Pfam database (available at https://pfam.xfam.org/) (Bateman et al. 2010; Finn et al. 2008). Currently, the number of protein families has dramatically been reported of almost upto 18,000 entries (El-Gebali et al. 2019). Identification of the DUFs that occur within the protein gains a better understanding on the function of proteins found in nature. The DUFs seem to be essential not only for the normal cellular function (Mashruwala \& Boyd 2018) but they also become more important particularly under certain conditions such as stress responses, biofilm formation, pathogenesis, intracellular metal homeostasis, environmental adaptation (Eletsky et al. 2014; Guo et al. 2016; Mashruwala \& Boyd 2018; Tong et al. 2016). Many of the DUFs are conserved and shared among prokaryotes and eukaryotes. For instances, the DUF59 has been documented to involve in intracellular Fe homeostasis in most of the organisms (Mashruwala \& Boyd 2018). The DUF2233, a protein domain with phosphodiester glycosidase activity, can be found in many bacteria, viruses and mammalian cells (Das et al. 2013). Even though, some of the DUFs (e.g. DUF2525, DUF2526 and DUF2545) have been conserved in many bacteria belonging to the family of Enterobacteriaceae, little is known about the regulation of DUFs in Enterobacter spp. Moreover, the role of DUFs on metal resistance mechanisms of the EC has never been explored.

In this study, isolation of Enterobacter cloacae from agricultural and industrial sites has been performed in order to search for the environmental isolates that possessed ability to tolerate and/or accumulate cadmium ions. Minimum inhibitory concentrations (MICs) together with binding capability to cadmium ions have been analyzed. Alterations of protein expression profiles upon exposure to toxic cadmium have subsequently been investigated using twodimensional-difference in gel electrophoresis (2D-DIGE) in conjunction with protein identification via liquid chromatography-mass spectrometry (LC-MS). Differentially-expressed proteins among different strains of $\mathrm{EC}$ as consequences of cadmium exposure have been analyzed and confirmed using qRT-PCR. In addition, molecular structure and functions together with their association networks have been determined by bioinformatic tools. Plausible explanations on the underlying mechanisms on how the EC respond and adapt themselves in survival against harmful cadmium have been discussed. 


\section{Materials \& Methods}

122

123

124

125

126

127

128

129

130

131

132

133

134

135

136

137

138

139

140

141

142

143

144

145

146

147

148

149

150

151

152

153

154

155

156

157

158

159

\section{Isolation and identification of bacteria from water and soil around agricultural and industrial sites}

Nine strains of bacteria were isolated from soil and water in various sites around agricultural and industrial areas in the central part of Thailand. Genus and species identification of these isolates was performed by Gram's staining and standard biochemical testings including triple sugar iron agar (TSI), lysine iron agar (LIA), sulfide-indole-motility (SIM), citrate and urease. These bacterial colonies were also subjected to MALDI/TOF mass spectrometry for further confirmation as follows. Isolated colonies were analyzed using a formic acid-based direct onplate preparation method. One microliter of $70 \%$ formic acid (Fluka, Sigma-Aldrich, St. Louis, USA) per well was deposited onto the MALDI-TOF-MS steel anchor plate (BigAnchor 96-well plate, Bruker Daltonics, USA). Colonies were smeared into the formic acid and allowed to dry. The dried mixture was overlaid with $2 \mu 1$ of matrix solution ( $\alpha$-cyano-4-hydroxycinnamic acid; HCCA) dissolved in 50\% acetonitrile, $47.5 \%$ water, and $2.5 \%$ trifluoroacetic acid (Fluka, SigmaAldrich) and allowed to dry prior to analysis using the MALDI Biotyper (Bruker Daltonics). A bacterial test standard (BTS, Bruker Daltonics) was used for instrument calibration. A positive control (Staphylococcus aureus ATCC 25923) and a negative control (formic acid and matrix) were included in each run. A MicroFlex LT mass spectrometer (Bruker Daltonics) was used for spectral analysis. Spectra were analyzed using the Bruker Biotyper 3.0 software and library version 3.3.1.0 (4,613 entries), supplemented with mass spectra from an in-house collection of 87 anaerobic isolates encompassing 39 species. Manufacturer-recommended cut-off scores were used for identification, with scores of $\geq 2.000$ indicating identification to the species level, scores between 1.700 and 1.999 indicating identification to the genus level, and scores of $<1.700$ indicating no identification. Isolates producing scores of $<1.700$ were retested once with the highest score used for final analysis. These nine isolates of Enterobacter cloacae were further deposited at $-80^{\circ} \mathrm{C}$ in the repository room (deposition reference numbers: EC_B-Cd-A series) at the Faculty of Medical Technology, Mahidol University, Salaya campus, Nakornpathom, Thailand.

\section{Determination of minimum inhibitory concentration (MIC) by agar dilution}

Determination of MIC by agar dilution was performed according to a standard guideline from the Clinical and Laboratory Standards Institute, 2012 (CLSI, 2012). Briefly, E. cloacae was incubated in the Luria-Bertani (LB) broth $(10 \mathrm{~g} / \mathrm{L}$ tryptone, $5 \mathrm{~g} / \mathrm{L} \mathrm{NaCl}$ and $5 \mathrm{~g} / \mathrm{L}$ yeast extract, $\mathrm{pH} 7.2$ ) at $37^{\circ} \mathrm{C}$ for overnight. Then, cells were collected and adjusted to be equivalent to 0.5 McFarland standard. Then, $2 \mu 1$ of ten-fold diluted of $0.5 \mathrm{McF}$ arland suspension was spotted onto each plate spreaded with final concentrations of cadmium, copper and zinc at 3.2-0.1 mM, 16-1 mM, and 6.4-0.1 mM, respectively. These plates were further incubated at $37^{\circ} \mathrm{C}$ for $18 \mathrm{~h}$ prior to the MIC analysis.

Peer) reviewing PDF | (2019:02:35301:1:1:NEW 31 Mar 2019) 
160

161

162

163

164

165

166

167

168

169

170

171

172

173

174

175

176

177

178

179

180

181

182

183

184

185

186

187

188

189

190

191

192

193

194

195

196

197

198

199

\section{Growth curves determination in the presence of sub-lethal dose of cadmium ions}

To observe the effect of cadmium ions on bacterial cells growth, overnight cultures of cells in $5 \mathrm{ml} \mathrm{LB}$ were adjusted to $\mathrm{OD}_{600}$ of 0.001 in a new tube containing $3 \mathrm{ml} \mathrm{LB}$ broth. Cells were grown at $37^{\circ} \mathrm{C}$ with shaking at $200 \mathrm{rpm}$ for $30 \mathrm{~min}$ prior to addition of $\mathrm{CdCl}_{2}$ to yield the final concentration of $0.2 \mathrm{mM}$. Each of bacterial isolates was taken into three replicates. These tubes were incubated in shaking incubator at $37^{\circ} \mathrm{C}$ at $200 \mathrm{rpm}$. Growth of cells was monitored by a spectrophotometer at the time interval of $1 \mathrm{~h}$ for $24 \mathrm{~h}$. It is noteworthy that the sub-lethal dose of $0.2 \mathrm{mM}$ cadmium ions was equivalent to $\mathrm{MIC} / 2$ of intolerant strain of $E$. cloacae (designated as EC07) and was selected as an effective dose for further experiments.

\section{Bacterial cell preparation in the treatment of cadmium ions}

Two strains of E. cloacae designated as EC01 and EC07 were considered according to their heavy metal tolerant ability as tolerant and intolerant strains, respectively. A standard strain of $E$. cloacae (ATCC 13047) was included for comparison. These isolates from frozen stock were initially grown in LB broth at $37^{\circ} \mathrm{C}$ for overnight. Then, bacteria were sub-cultured onto LB agar and further incubated at $37^{\circ} \mathrm{C}$ for overnight. With three biological replicates, three isolated colonies were inoculated into $50 \mathrm{ml}$ of LB broth and incubated at $37^{\circ} \mathrm{C}$ for $18 \mathrm{~h}$. Cells were collected and adjusted to equal cell density at $\mathrm{OD}_{600}$ of approximately 4.0 in $50 \mathrm{ml} \mathrm{LB}$ broth. Cells were initially grown at $37^{\circ} \mathrm{C}, 200 \mathrm{rpm}$ for $30 \mathrm{~min}$ before treatment with or without $0.2 \mathrm{mM}$ $\mathrm{CdCl}_{2}$. Cells were further incubated for $6 \mathrm{~h}$ and harvested by centrifugation at 14,000 rpm for 30 min at $4^{\circ} \mathrm{C}$. Pellets were washed five times with Tris-sucrose buffer ( $1 \mathrm{mM}$ Tris-base, $250 \mathrm{mM}$ sucrose, $\mathrm{pH} 7.2$ ) at $14,000 \mathrm{rpm}$ for $30 \mathrm{~min}$ at $4^{\circ} \mathrm{C}$ to remove the excess salts and heavy metals. The bacterial cells were divided into two parts: first part was prepared for proteomics analysis and another for cadmium accumulation analysis and every step was done on ice. The pellets were stored at $-80^{\circ} \mathrm{C}$ for proteomics analysis.

\section{Intracellular cadmium accumulation analysis}

For cadmium accumulation analysis, cells from the previous step were adjusted to $\mathrm{OD}_{600}=$ 1.0 in $3 \mathrm{ml}$ of Tris-sucrose buffer and were centrifuged at $14,000 \mathrm{rpm}, 4^{\circ} \mathrm{C}$ for $30 \mathrm{~min}$. Then, the supernatant was removed and $500 \mu \mathrm{l}$ of concentrated nitric acid was added to the pellet and kept for overnight. The amounts of cadmium accumulation in bacterial cells were measured by atomic absorption spectroscopy (Varian SpectrAA-640, USA) and SpectrAA 200 software (Varian, USA). Briefly, a cadmium stock standard solution $(1,000 \mu \mathrm{g} / \mathrm{ml})$ was diluted to various concentrations with $0.2 \% \mathrm{HNO}_{3}$ and served as working standard solutions. Then, the calibration curve $(0-1,000 \mu \mathrm{g} / \mathrm{L})$ was prepared using blank and working standard solutions under the preset parameters (wavelength $228.8 \mathrm{~nm}$ with $0.5 \mathrm{~nm}$ slit width and the characteristic concentration check ( $\sim 0.2$ absorbance unit) at $0.5 \mathrm{mg} / \mathrm{L})$. The sample blank contained all reagents used in the sample preparation. Samples were diluted 20 fold prior to cadmium determination and the amount of cadmium was subsequently recorded. 
200

201

202

203

204

205

206

207

208

209

210

211

212

213

214

215

216

217

218

219

220

221

222

223

224

225

226

227

228

229

230

231

232

233

234

235

236

237

238

239

\section{Proteomics analysis}

Proteins extraction. The bacterial pellets were resuspened in $2 \mathrm{x}$ volumes of sample of lysis buffer ( $2 \mathrm{M}$ thiourea, $7 \mathrm{M}$ urea, 4\% CHAPS, and 1\% protease inhibitors cocktail). The bacterial cells were disrupted by sonicator (Amplitude 60, 0.5 cycles) on ice. Then, samples were centrifuged at $14,000 \mathrm{rpm}$ for $30 \mathrm{~min}$ at $4^{\circ} \mathrm{C}$. Protein concentration was measured by Bradford's method (Bio-Rad protein assay, Bio-Rad Laboratories, USA). The protein samples were collected and stored at $-80^{\circ} \mathrm{C}$.

Minimal labeling of protein sample. Protein extracts were initially cleaned-up by using the 2-D Clean-up kit (GE Healthcare, USA). Then, the proteins of all samples were labeled with Nhydroxy succinimidyl ester-derivatives of the cyanine dye Cy2, Cy3 and Cy5 (GE Cydye DIGE Fluor (minimal dyes) Labeling Kit (GE Healthcare) following the manufacturer' protocols. Briefly, the internal standard pool was generated by combining equal $25 \mu \mathrm{g}$ of extracts from all samples and then the pooled sample was labeled with 400 pmol of $\mathrm{Cy} 2$ to aid image matching and cross-gel statistical analysis. The $50 \mu \mathrm{g}$ proteins from control and cadmium treated cell were minimally labeled with 400 pmol of Cy3 or Cy5. The samples were vortexed and kept on ice for $30 \mathrm{~min}$ in the darkness. Then, the reaction was terminated by addition of $1 \mu 1$ of $10 \mathrm{mM}$ lysine and subsequently incubated on ice for $10 \mathrm{~min}$ in the darkness.

First-dimensional gel electrophoresis. The total of $50 \mu \mathrm{g}$ protein of each sample, which randomly labeled with $\mathrm{Cy} 3$ or $\mathrm{Cy} 5$, and the internal standard $\mathrm{Cy} 2$, were mixed together and applied to $120 \mu \mathrm{l}$ of rehydration buffer ( $8 \mathrm{M}$ urea, 4\% CHAPS, $0.001 \%(\mathrm{w} / \mathrm{v})$ bromophenol blue), $3 \mathrm{mM}$ of dithiothreitol (DTT) and 1.75 $\mu 1$ 1\% IPG buffer 3-10 NL). In parallel, $360 \mu 1$ of rehydration buffer was applied into rehydration tray and strip was placed. Then, the strips were rehydrated in rehydration solution at $20^{\circ} \mathrm{C}$ for $16-20 \mathrm{~h}$. The total $150 \mu \mathrm{g}$ of pooled labeled cy 3 , cy5 and cy 2 samples were focused in a broad range of $18 \mathrm{~cm}, 3-10 \mathrm{NL}$ of IPG strips (GE healthcare) using cup-loading technique and the isoelectric focusing was carried out using an IPGphor III apparatus (GE Healthcare) according to the following procedures: 500 volts for 500 volt-h, 1,000 volts for 800 volt-h, and 10,000 volts to reach 27,000 volt-h.

Second-dimensional gel electrophoresis. The $12.5 \%$ polyacrylamide gel was prepared at room temperature for $16-18 \mathrm{~h}$ for gel polymerization. The strips were equilibrated twice $(15 \mathrm{~min}$ per each) in equilibrium buffer (50 mM Tris pH 8.8, $6 \mathrm{M}$ urea, 30\% glycerol, 2\% SDS, 0.03\% bromophenol blue) supplemented with $65 \mathrm{mM}$ DTT or $135 \mathrm{mM}$ iodoacetamide. Then, the equilibrated IPG strips were laid onto the surface of a vertical $12.5 \%$ polyacrylamide gel and covered with $0.5 \%$ agarose gel and $10 \%$ bromophenol blue. Separation of protein was carried out at 2.5 watt per gel at $20^{\circ} \mathrm{C}$ for 30 min following by 10 watt per gel at $20^{\circ} \mathrm{C}$ until the bromophenol blue dye front reached $0.5 \mathrm{~cm}$ from the bottom of the gel.

Image analysis. 2D-DIGE gel images were acquired using Typhoon TRIO Variable Mode Imager (GE Healthcare). Differential analysis was performed by ImageMaster 2D Platinum version 7.0 (GE Healthcare) software tool. These included spot intensity calibration, spot detection and background subtraction. Quantification of intensity of each spot was performed in terms of spot volume (area $\times$ intensity). The total spot volume normalization method was applied 
240 in which the percentage of each spot volume on a gel image is calculated relative to the total 241 volume of all spots on that image. Then, determination of differentially expressed proteins was

242 conducted by comparing the ratio of $\%$ volume values with control and kept at $4{ }^{\circ} \mathrm{C}$ until protein 243 identification.

244 Gel staining. Gels were stained with Colloidal coomassie brilliant blue staining $(10 \%(\mathrm{w} / \mathrm{v})$ 245 ammonium sulfate, $1 \%(\mathrm{v} / \mathrm{v})$ phosphoric acid, $0.1 \%(\mathrm{w} / \mathrm{v})$ Coomassie blue) for overnight. 246 Finally, the gels were destained with milli-Q water until a clear background was observed.

247

248

249

250

251

252

253

254

255

256

257

258

259

260

261

262

263

264

265

266

267

268

269

270

271

272

273

274

275

276

277

278

279

Protein identification. The QTOF-LC-MS/MS system consisting of a liquid chromatography part (Ultimate 3000, thermo Scientific) in combination with an electrospray ionization (ESI) Quadrupole time of flight mass spectrometer (Model Amazon SL, Bruker, Germany) was used for protein identification. Protein spots of interest were digested by trypsin. First, the protein spots were excised from 2-DE gel and washed twice with $50 \mu 1$ of $50 \%$ acetronitrile (ACN)/25 $\mathrm{mM}$ ammonium bicarbonate $\left(\mathrm{NH}_{4} \mathrm{HCO}_{3}\right)$ at room temperature for $15 \mathrm{~min}$. Then, the solvent was removed and $50 \mu 1$ of $100 \%$ acetonitrile was added for $10 \mathrm{~min}$ or until all gels were in white. After that, the acetonitrile was removed and $5 \mu \mathrm{l}$ of diluted trypsin (diluted $0.1 \mathrm{mg} / \mathrm{ml} \mathrm{stock}$ trypsin 1:10 into $25 \mathrm{mM}$ ammonium bicarbonate) was added into each tube at $37^{\circ} \mathrm{C}$ for $16-24 \mathrm{~h}$. Next, the supernatants were removed to new tubes. Peptides were extracted twice by $15-25 \mu 1$ of $50 \%$ acetonitrile, $5 \%$ trifluoroacetic acid (TFA) to each tube containing gel slice for $15 \mathrm{~min}$. Then, the extracted peptides were removed and combined with the supernatant in the new tube. Finally, the extracted peptides were dried in a vacuum centrifuge to dryness. For sample analysis by QTOF-LC-MS/MS, peptides were separated on a reversed phase column (Hypersil GOLD $50 \times 0.5 \mathrm{~mm}, 5 \mu \mathrm{m} \mathrm{C} 18)$ and eluted at a flow rate of $100 \mu \mathrm{l} / \mathrm{min}$ under gradient condition of 5$80 \%$ B over 50 min mobile phase A consists of water/formic acid $(99.9: 0.1, \mathrm{v} / \mathrm{v})$ and B consists of acetonitrile/water/formic acid (80:20:0.08, v/v). Mass spectral data from 300 to 1,500 m/z were collected in the positive ionization mode. To identify the protein, all MS/MS spectra recorded on tryptic peptides derived from spots were searched against protein sequences from NCBInr databases using the MASCOT search engine program (available at www.matrixscience.com). The functional analysis of protein was performed on UniProtKB database at 'https://www.uniprot.org/help/uniprotkb'.

\section{Unknown protein searching}

The amino acid sequences of unknown protein were searched on 'https://blast.ncbi.nlm.nih.gov/Blast.cgi' using 'non-redundant protein sequences (nr)' database. Then, the secondary structures of unknown protein were predicted by PSIPRED 'server:bioinf.cs.ucl.ac.uk/psipred/'. At last, the tertiary structure was predicted by SWISSMODEL server 'https://swissmodel.expasy.org/interactive'.

\section{Protein network analysis}

Protein association networks were created by subjecting the identified proteins to the STRING software version 9.05 (http://string-db.org/). Direct (physical) and indirect (functional)

Peer) reviewing PDF | (2019:02:35301:1:1:NEW 31 Mar 2019) 
280

281

282

283

284

285

286

287

288

289

290

291

292

293

294

295

296

297

298

299

300

301

302

303

304

305

306

307

308

309

310

311

312

313

314

315

316

317

318

319

associations were weighted and integrated by using various data, e.g. genetic context, highthroughput experiments, co-expression and previous knowledge, from the database.

\section{Statistical analysis}

All data are expressed as mean \pm standard deviation (SD). For group comparisons, data were determined by analysis of variance (ANOVA). The strength of each association is presented as the regression coefficient with $95 \%$ confidence interval and $P$-value. A $P$-value $<0.05$ was considered statistically significant.

\section{Confirmation of gene expression by qRT-PCR analysis}

$R N A$ isolation and quantification. Bacterial cell suspension was centrifuged for cells harvesting. A $0.75 \mathrm{ml}$ of TRIzol ${ }^{\mathrm{TM}}$ reagent (Thermo Fisher Scientific, USA) was added to $1 \times 10^{7}$ cells of EC. Cells were lysed by pipetting-up and -down several times. The homogenized samples were transferred to $1.5 \mathrm{ml}$ microcentrifuge tube and further incubated for $5 \mathrm{~min}$ at room temperature for completing the dissociation of the nucleoprotein complex. Then, $0.2 \mathrm{ml}$ chloroform (Sigma-Aldrich Chemical Co., USA) was added. Tubes were further mixed vigorously by hand for $15 \mathrm{sec}$ and incubated for $2 \mathrm{~min}$ at room temperature. After that, the samples were centrifuged at $14,000 \mathrm{rpm}$ for $15 \mathrm{~min}$ at $4^{\circ} \mathrm{C}$. The mixture was separated into a lower red phenol-chloroform phase, an interphase, and a colorless upper aqueous phase. Since the RNA remained in the aqueous phase so the aqueous phase of the sample was removed by angling the tube $45^{\circ}$ and pipetting the solution out to new centrifuge tube. For RNA precipitation, $0.5 \mathrm{ml}$ of isopropanol (Sigma-Aldrich Chemical Co., USA) was added to the aqueous phase tubes and incubated at room temperature for $10 \mathrm{~min}$. Tube was centrifuged at $14,000 \mathrm{rpm}$ for $10 \mathrm{~min}$ at $4^{\circ} \mathrm{C}$. Finally, the RNA forms a gel-like pellet on the side and bottom of the tube. After precipitation and centrifugation, the supernatant was removed, leaving only RNA pellet. The RNA pellet was washed with $75 \%$ ethanol and vortexed briefly. Then, it was centrifuged at 9,000 rpm for $5 \mathrm{~min}$ at $4^{\circ} \mathrm{C}$ and discarded the wash. The RNA pellet was dried by air for 5-10 min. To quantify the RNA concentration, the RNA pellet was dissolved in $20 \mu 1$ DEPC-treated water. RNA concentration was quantified with the Nano-Drop Spectrophotometer. RNA quality was evaluated by the absorbance $260 / 280 \mathrm{~nm}$ and $260 / 230 \mathrm{~nm}$ ratios with value $>1.8$ and $>2.0$, respectively.

$c D N A$ synthesis. RNA was reverse transcribed into cDNA using SuperScript ${ }^{\circledR}$ III reverse transcriptase (Thermo Fisher Scientific). The reverse transcription-polymerase chain reaction (RT-PCR) was performed using Mastercycler nexus X2 (Eppendorf, USA). Firstly, each reagent was mixed and briefly centrifuged before use. Starting material of cDNA synthesis was prepared from $5 \mu \mathrm{g}$ of total RNA, $1 \mu \mathrm{l}$ of $50 \mu \mathrm{M}$ oligo(dT) $)_{20}$ primer, $1 \mu \mathrm{l}$ of $10 \mathrm{mM}$ dNTP mix and DEPCtreated water was added until total volume to $10 \mu \mathrm{l}$ in $0.5 \mathrm{ml}$ tube. Then, the tube was incubated at $65^{\circ} \mathrm{C}$ for $5 \mathrm{~min}$ and placed on ice for at least $1 \mathrm{~min}$. After that, cDNA synthesis was prepared by mixing of $2 \mu \mathrm{l}$ of $10 \mathrm{x}$ RT buffer, $4 \mu \mathrm{l}$ of $25 \mathrm{mM} \mathrm{MgCl}_{2}, 2 \mu \mathrm{l}$ of $0.1 \mathrm{M} \mathrm{DTT}, 1 \mu \mathrm{l}$ of $\operatorname{RNaseOUT}^{\mathrm{TM}}(40 \mathrm{U} / \mu \mathrm{l})$ and $1 \mu \mathrm{l}$ of SuperScript ${ }^{\circledR}$ III RT (200 U/ $\left.\mu 1\right) .10 \mu \mathrm{l}$ of cDNA synthesis mix 
320

321

322

323

324

325

326

327

328

329

330

331

332

333

334

335

336

337

338

339

340

341

342

343

344

345

346

347

348

349

350

351

352

353

354

355

356

357

358

was added to RNA-primer mixture, mixed gently, and incubated at $50^{\circ} \mathrm{C}$ for $50 \mathrm{~min}$. The reaction was terminated at $85^{\circ} \mathrm{C}$ for 5 min and chilled on ice. Finally, $1 \mu$ of RNaseH was added to each tube and incubated at $37^{\circ} \mathrm{C}$ for $20 \mathrm{~min}$ to hydrolyze specifically the phosphodiester bonds of RNA hybridized to DNA. cDNA was stored at $-20^{\circ} \mathrm{C}$ until use for PCR. cDNA concentrations were measured following the RT reaction with the Nano-Drop Spectrophotometer.

Quantitative reverse transcription-polymerase chain reaction ( $q R T-P C R$ ). The resulting cDNA was used in a $20 \mu \mathrm{l}$ reaction that contained $1 \mu \mathrm{cDNA}, 10 \mu \mathrm{SYBR}{ }^{\circledR}$ Green mix (Bio-Rad Laboratories, USA), $0.4 \mu \mathrm{l}$ of specific primer sets, the DUF326 forward: $5^{\prime}$ GTTTGCGCTGATGTGTGTCA-3' and reverse: 5'-GCCATCCTTCGGCATTGTTC-3'; the GAPDH forward: 5'-CAGATGTCATTGGCTCGCAC-3' and reverse: 5'-

AGTGCGGCGTATTTATCAAGCG-3'; Then, DEPC-treated water was added until the total volume of $20 \mu$. Parameters for PCR amplification were as $95^{\circ} \mathrm{C}$ for 3 min for enzyme activation, followed by 40 cycles each consisting of denaturation at $95^{\circ} \mathrm{C}$ for $3 \mathrm{sec}$, annealing at $54^{\circ} \mathrm{C}(D U F 326)$ and $59^{\circ} \mathrm{C}(G A P D H)$ for $30 \mathrm{sec}$ and extension at $72^{\circ} \mathrm{C}$ for $20 \mathrm{sec}$. The $G A P D H$ was used as reference gene to normalize values. Relative quantification calculations were performed by $\Delta \Delta \mathrm{Cq}$ value.

\section{Results}

\section{Bacterial identification and minimum inhibitory concentrations (MICs) of cadmium ions in} Enterobacter cloacae isolated from water and soil

All 9 isolates were identified by conventional biochemical identification and further confirmed as Enterobacter cloacae with the high scores of 2.013-2.255 by MALDI-Biotyper (Table 1). The MICs of cadmium ions in these isolates were mostly in the range of $0.8-1.6 \mathrm{mM}$ (Table 2). There were only two isolates, namely EC01 and EC08, which exhibited the MICs at $1.6 \mathrm{mM}$. However, it seems that the EC01 could tolerate the other metal ions (e.g. zinc and copper) approximately 2 fold higher than those of the EC08 strain. The same degree of tolerance against these three kinds of metal ions was also found in the standard strain (ATCC 13047). To further elucidate the cellular responses and the underlying mechanism against cadmium ions, the EC07 (isolated from the cleaned area) was selected since it showed 4 fold lower in MIC than that of the EC01 strain while displaying the same degree of tolerance against zinc and copper ions. Therefore, in the present study, 3 strains of E. cloacae (EC01, EC07 and ATCC 13047) were selected for further experiments.

\section{Growth patterns of $E$. cloacae isolates in the presence of sub-lethal dose of cadmium ions}

To investigate the growth patterns of these 3 strains in the presence of cadmium ions, the final concentration of $0.2 \mathrm{mM} \mathrm{CdCl}_{2}$ represented as $\mathrm{MIC} / 2$ of the most sensitive strain (EC07) was selected. As shown in Fig. 1B, some suppressing effect on the growth arrest of EC01 was found at the lag phase and early-log phase while the rate of cell division at the middle- to late-log phase resembled those in the absence of cadmium ions. Such recovery was not significantly 
359

360

361

362

363

364

365

366

367

368

369

370

371

372

373

374

375

376

377

378

379

380

381

382

383

384

385

386

387

388

389

390

391

392

393

394

395

396

397

detected in the case of ATCC 13047 (Fig. 1A). Not surprisingly, cadmium ions at $0.2 \mathrm{mM}$ exerted their toxic effects on the growth of EC07 at all phases of cell division (Fig. 1C).

\section{Cadmium accumulation at the cellular and protein levels}

Next question was addressed on whether the tolerance phenomenon found in EC01 associated with the higher cadmium accumulation intracellularly. As illustrated in Fig. 2, the higher cadmium adsorptivity of upto 2.7-3.0 $\mu \mathrm{g}$ per $8 \times 10^{8} \mathrm{cells}$ was found in the case of EC01, particularly at $6 \mathrm{~h}$, as compared to the others. Importantly, when quantification of cadmium adsorption was performed in the whole cell lysates, the proteins portion of EC01 provided binding capability of approximately 2 fold higher than those of the ATCC 13047 and EC07 strains (Fig. 3). Our findings lend support to the hypothesis that the EC01 expressed some of the cadmium-responsive proteins differently from those of the others.

\section{Protein expression profiles of $E$. cloacae in the presence of cadmium ions revealed by 2D- DIGE}

To further explore the detailed mechanism on how E. cloacae initially responded and adopt themselves upon exposure to cadmium toxicity in a short period of time $(6 \mathrm{~h})$, two-dimensionaldifference in gel electrophoresis (2D-DIGE) in conjuction with protein identification via mass spectrometry was utilized. As demonstrated in Fig. 4, approximately 250 protein spots were detected in the master map of pooled proteins (labeled with Cy2) served as an internal standard for these three isolates. Eighty protein spots were then picked up and analyzed by the QTOF-LCMS/MS system for protein identification (Table 3). Most of the proteins were classified by UniProtKB to be responsive for oxidative stress, protein folding, glycolytic process, translation, metal ion binding, ion transport and homeostasis (Fig. 5). Up- or down-regulations of protein in E. cloacae ATCC 13047, EC01 and EC07 strains were summarised in Table 3. In case of ATCC 13047, up-regulation of catalase (spots 2 and 4), Hsp20 (spot 28), malate dehydrogenase (spot 32 ), glyceraldehyde-3-phosphate dehydrogenase (spots 36 and 37), superoxide dismutase (spot 38), fructose-bisphosphate aldolase (spot 46), GroEL (spots 55, 56 and 59), putative hydrolase (spot 58), ATP synthase (spot 67) was detected in response to cadmium toxicity. For the EC01, a set of protein similar to those of the ATCC strain was up-regulated such as catalase (spots 1,2 and 3), Hsp20 (spot 28), malate dehydrogenase (spot 32), glyceraldehyde-3-phosphate dehydrogenase (spots 36 and 37), fructose-bisphosphate aldolase (spot 46) and GroEL (spots 55, 56 and 59). Meanwhile, up-regulation of some proteins including dihydrolipoamide dehydrogenase (spot 10), enolase (spot 52), domain of uncharacterized function (DUF 326) (spot 57), aspartate ammonia-lyase (spot 60) and glutamine-binding periplasmic protein (spot 79) was found in the EC01. The protein profile of EC07 showed the up-regulation of catalase (spot 3), hydroperoxidase (spot 11), Dps (spot 19), OmpX (spot 23), YciF protein (spot 27), TrpR binding protein WrbA (spot 29), OmpC porin (spot 45), glucose-specific PTS system (spot 68) and glutamine-binding periplasmic protein (spot 79). 
407

408

409

410

411

412

413

414

415

416

417

418

419

420

421

422

423

424

425

426

427

428

429

430

431

432

433

434

435

436

437

To further simplify the groups of protein shown as unique or overlap proteins among these 3 strains of E. cloacae, Venn diagram was plotted as illustrated in Fig. 6. Catalase was analyzed to be the only one protein found in all 3 strains under cadmium stress. Four proteins namely enolase, DUF326-like domain, dihydrolipoamide dehydrogenase, aspartate ammonia-lyase were detected as unique proteins in the case of tolerant strain (EC01). In the intolerant strain (EC07), the unique proteins were identified as OmpX, protein YciF, OmpC porin, DNA protection during starvation protein, and TrpR binding protein WrbA. However, our finding revealed that glutamine-binding periplasmic protein was the only one protein shared between EC01 and EC07 strains.

\section{Identification of specific cadmium-induced protein alterations in EC01 (tolerant strain) and EC07 (intolerant strain)}

Differentially expressed proteins found in EC01 as compared to those of the EC07 strain in the presence of cadmium ions were analyzed as shown in Tables 4 and 5. DUF326-like domain was analyzed to show the highest difference in fold change (+220.92 fold) of protein expression between EC01 and EC07 (Table 4). This indicates that the EC01 normally expresses the DUF326-like domain at high level when grows up in the environmental-contaminated site. Therefore, exposure to cadmium ions at $0.2 \mathrm{mM}$ in a short period of time $(6 \mathrm{~h})$ triggered the cells to up-regulate the DUF326-like domain expression of only 1.35 fold higher than that in the absence of cadmium. Similar phenomena were also found in the regulation of antioxidative enzymes such as hydroperoxidase II $(+42.3$ and +21.3 fold $)$ and superoxide dismutase $(+8.14$ fold), expression of periplasmic protein ( +14.3 fold) or outer membrane protein $X(+6.98$ fold) as well as the metabolic enzyme (MDH; +7.45 fold) as compared to very low/undetectable amount found in the control. Beside these, differences in expression of the other proteins were found in the range of 1.38-6 fold higher than those of the EC07 in response to the toxic cadmium ions.

As compared to the results of EC07 shown in Table 5, the EC01 exhibited lower expression of YciF protein of approximately 84.7 fold than that of the EC07. Expression of the OmpC porin and manganese catalase of upto 53.2 and 51.7 fold lower than those of the EC07 was also detected. More than 30 fold difference in the osmotically-inducible protein $\mathrm{Y}$ and Dps were recorded. Expression of the other proteins was varied in the range of 1.3-29.2 fold.

To further confirm whether cadmium stress affected gene expression of E. cloacae, Fig. 7 depicts qRT-PCR analysis of DUF326-like domain expression. Data are normalized relative to GAPDH gene (served as a house keeping gene) and expressed as the fold difference $\left(2^{-\Delta \Delta \mathrm{Cq}}\right)$ between control and cadmium-treated group. Expression of DUF326 gene in E.cloacae strain 01, 07 and ATCC were at 14.13, 1.28, 1.49-fold higher in cadmium-treated than in the control group, respectively.

\section{Discussion}

Cadmium contamination remains a major health concern due to its toxicity to human, animals and microorganisms. Searching for bacteria that possess high capability to bind 
438 cadmium ions and/or cadmium tolerance is needed for further applying as bioremediation tool. 439 E. cloacae has been isolated and characterized as a potential heavy metal accumulating bacteria 440 (Iyer et al. 2004; Naik et al. 2012; Rahman et al. 2015). However, the global-protein response to 441 cadmium of E. cloacae is still unclear. In this study, the cadmium-tolerant $E$. cloacae isolated 442 from agricultural and industrial area were collected. Minimium inhibitory concentrations (MICs) 443 and growth patterns in the presence of cadmium ions have been tested. As expected, the tolerant 444 strain (EC01) with the MIC of $1.6 \mathrm{mM}$ cadmium has been isolated from industrial effluents of heavy metal area whereas the intolerant strain (EC07) (MIC at $0.4 \mathrm{mM}$ ) has been isolated from the cleaned area. Even though, the ATCC 13047 exhibited the same MIC as that of the EC01, recovery of growth pattern during exposure to cadmium was in a lesser extent than the EC01. Moreover, the degree of cadmium binding by the whole cell lysate of EC01 was approximately 2 fold higher than those of the ATCC 13047 and EC07. Such cadmium binding property opens up a high feasibility of utilizing as biosorbents for cadmium remediation as in case of the exopolysaccharides (Iyer et al. 2005).

To explore the underlying mechanisms of E. cloacae in response to cadmium toxicity, proteomics profiling of these three strains were carried out by 2D-DIGE technology. DIGE (Difference in Gel Electrophoresis) was conducted in this experiment to overcome the gel-to-gel variation, which might be resulted from gel casting, running and staining. The system is based on the specific properties of CyDye ${ }^{\mathrm{TM}}$ DIGE Fluor dyes that enable multiplexing of separate protein mixtures on the same 2-D gel. The mixing sample with internal standard (pooled samples) technique allows for multivariable analyses, as samples can be separated and compared on several DIGE gels that were co-ordinated by the internal standard. The ability to directly compare two samples on the same gel not only avoids the complications of gel-to-gel variation but also enables a more accurate and rapid analysis of differences and reduces the number of gels that need to be run (Westermeier \& Scheibe 2008). Up- or down-regulation of protein expression among these three strains is summarized in Tables 3-5 and the presumtive conclusion can be emphasized as followings.

\section{Catalase isoforms serve as common adaptive responses of $E$. cloacae upon exposure to toxic cadmium}
Cadmium ions exert their toxicity on the growth of E. cloacae in different degree of inhibition, depending on the protein expression in each strain (Fig. 1). These toxic effects possibly derived from the generation of reactive oxygen and nitrogen species (ROS and RNS) (Brennan \& Schiestl 1996; Isarankura-Na-Ayudhya et al. 2018; Stohs \& Bagchi 1995). Such free radical was not mainly produced by cadmium itself, however, indirect formation of ROS and RNS e.g. superoxide radical, hydroxyl radical and nitric oxide has been reported (Waisberg et al. 2003). Generation of non-radical hydrogen peroxide, which itself may in turn be a significant source of radicals via Fenton chemistry, was thought to be involved in this process. Furthermore, cadmium was also proposed to replace copper and iron in various cytoplasmic and membrane proteins such as ferritin, apoferritin. This resulted in the increase amount of free copper and iron, 
478 which consequently participated in oxidative stress via Fenton reactions (Price \& Joshi 1983). In

479 this study, the catalase was found to be the only one protein shared among all three strains in the 480 presence of cadmium stress (Fig. 6). Enhancement of catalase activity was also observed in the 481 EC strain B1 when cultured in the cadmium condition (Banerjee et al. 2015). Importantly, the 482 catalase has been proven to be the major enzyme used to detoxify these harmful effects in the 483 case of ATCC 13047 (Fig. 8C). Even though, the tolerant strain (EC01) did not use the catalase 484 as the primary responses but it showed a specific pattern of catalase expression (spots no. 1, 2, 6 485 and 7). It should also be noted that spot no. 8 was found to be unique in the intolerant strain 486 (EC07) (Table 3). Supportive evidences were documented on the presence of different isoforms 487 of catalase found in Pseudomonas aeruginosa and $P$. stutzeri under various growth conditions 488 such as under starvation conditions, induced by exposure to S-nitrosoglutathione (nitric 489 oxide-generating reagent), and induced by exposure to sodium nitroprusside (Kawakami et al. 490 2010; Xie et al. 2014). In addition, Xanthomonas campestris responded against cadmium stress 491 by regulation of two monofunctional catalase isozymes (Banjerdkij et al. 2005). Therefore, up492 regulation of catalase found herein was proposed not only to associate with an adaptation of $E$. 493 cloacae in survival under oxidative stress but also to reduce ROS in the cells due to Cd actions. 494 Moreover, the bacteria selected different isoforms of catalase in manner of Cd responses.

495

496

\section{DUF326-like domain: a novel molecule participated in detoxification of cadmium stress}

It has been suggested that the EC01 could tolerate to toxic cadmium by expressing cadmium-binding proteins (Fig. 3). This coincided with the high level expression of the DUF326-like domain (Table 4 and Fig. 8A). To our knowledge, this is the first report on the

501 involvement of DUF326-like domain in detoxification of cadmium stress in bacteria since the world-wide availability of molecular function of DUF326 is quite limited

503 (www.ebi.ac.uk/interpro/entry/IPR005560). When the DUF326-like domain was subjected to

504 blast on https://blast.ncbi.nlm.nih.gov/Blast.cgi, the results showed 100\% identity with four helix

505 bundles copper-binding protein (Fig. 9) of Family 'Enterobecteriaceae'. The copper-binding protein is a cysteine-rich protein that can be found in many copper resistant bacteria. Previous study demonstrated that Pseudomonas putida expressed three Cd-binding proteins (CdBP1, $\mathrm{CdBP} 2$ and $\mathrm{CdBP} 3$ ), which contain large amounts of cysteine residue. Among these, the CdBP3 has the highest cysteine content of $22 \%$ (Higham et al. 1983). Compared to our finding, the DUF326 protein comprises of 19 cysteine residues from 108 amino acid (17.6\%) (Fig. 9). It can be suggested that the thiol groups derived from these cysteine-rich proteins provide very high binding avidity to $\mathrm{Cd}$. Additionally, protein sequence analysis by searching on UniProtKB database described that the cysteines mostly follow a C-X(2)-C-X(3)-C-X(2)-C-X(3) pattern,

514 (https://www.ebi.ac.uk/interpro/entry/IPR005560). The result from domain architecture mode 515 analysis had shown two domain types including 4Fe-4S ferredoxin-type, iron-sulphur binding 516 domain (IPR017896) found in the DUF326. Similar observation was also found in the DUF59 517 that involved in FeS protein maturation and/or intracellular Fe homeostasis (Mashruwala \& Boyd 
518 2018). Supportive evidences on the interconnection between DUF326 and 4Fe-4S ferredoxin 519 protein $(\mathrm{YwjF})$ and other related iron-sulfur containing proteins were identified by the STRING 520 database as shown in Fig. 10.

521 Overexpression of DUF326-like domain was believed to protect the E. cloacae from 522 hazardous cadmium ions, possibly by high binding affinity to cadmium. It has extensively been 523 reported the imperative roles of domain of unknown function on stress responses in many 524 organisms as follows. In P. aeruginosa, induction of PA1994 (classified as a member of 525 DUF1089) was proposed to be responsive for the bacterial cell-wall stress or host-pathogen 526 interactions (Bakolitsa et al. 2010). The DUF1471 found in many bacteria in the

527 Enterobacteriaceae played roles in stress response, biofilm formation, and pathogenesis (Eletsky 528 et al. 2014). In fungus, the DUF1996 regions involved in the regulation of multiple stress 529 responses and environmental adaptation (Tong et al. 2016). In rice, the DUF1644 and DUF966 530 genes were regulated in response to drought and salinity stresses (Guo et al. 2016; Luo et al. 531 2014).

532

Protein networks involved in the survival of intolerant strain of $E$. cloacae in cadmium stress

535

In case of EC07, the top-ranked of protein expression in survival against cadmium stress included the YciF protein, OmpC porin, manganese catalase, Osmotically-inducible protein Y, DNA protection during starvation protein, and OsmC family protein (Table 5). Expression of the YciF protein, which is a stress-inducible protein, was found to be in the highest level. The

539 structure and function of this protein have not extensively been studied. After searching in UniProtKB/TrEMBL database, the YciF might contain some components closed to the DUF892 family that possessed iron sequestration funtion (Liu et al. 2016). It is possible that the YciF is up-regulated when the bacteria encounter stress conditions. From the crystal structure of YciF protein of Escherichia coli (Hindupur et al. 2006), a hypothesis can be emphasized that the YciF may possess metal-binding properties since its structure is similar to others metal-binding proteins such as rubrerythrin (a protein that has a di-iron center), ferritin and monooxygenases (Hindupur et al. 2006). The metal-binding sites are proposed to lie in the helix bundle within the two pockets (P1 and P2). The architectural features of YciF are also found to associate with other protein functions such as the manganese catalase domain in the protein bll3758 from Bradyrhizobium japonicum (Hindupur et al. 2006).

550

Using the STRING software, the YciF protein has a direct interconnection with the OsmC (encoding peroxiredoxin) (Fig. 11). In addition, it has some indirect connection with a series of outer membrane proteins $(\mathrm{OmpC}, \mathrm{OmpA}$ and $\mathrm{OmpX})$ linked by the YdeI protein (induced by cadmium, hydrogen peroxide and acid stress) (Lee et al. 2010). The OmpC porin is known to involve in biological process as ion transport system. This protein has been reported mostly to participate in antibiotic resistant mechanism of E. cloacae. Disruption of OmpC rendered the correlation between cadmium stress and alteration in $\mathrm{OmpC}$ porin. In the present study, the fold 
558

559

560

561

562

563

564

565

566

567

568

569

570

571

572

573

574

575

576

577

578

579

580

581

582

583

584

585

586

587

588

589

590

591

592

593

594

595

596

597

difference in expression of OmpC porin between the EC07 and EC01 was approximately 53 fold (Table 5). Similar observation was also found in E. coli in which deletion of OmpC gene led to decreased cadmium resistance (Egler et al. 2005). Additionally, it is noteworthy that there is a linkage between the OsmC and Dps proteins. More importantly, there is a high possibility that the Dps might be a connecting junction with the other proteins involved in the metabolic processes (glycolysis and tricarboxylic acid cycle), ATP production, chaperone and oxidative scavenging enzyme.

The increase of Dps under cadmium-stress condition might be associated with DNA protection of $E$. cloacae to survive. A previous study mentioned that the levels of cellular DNA damage were significantly higher in cadmium adding in cultures than in controls (Shapiro \& Keasling 1996). Explanation can be drawn that a mutagenic effect by cadmium is not due to direct interaction with DNA but rather to inhibit DNA repair systems (Serero et al. 2008). The Dps was also reported to be expressed during stationary phase upon starvation or exposure to severe environmental assaults, including oxidative stress and nutritional deprivation (Calhoun \& Kwon 2011; Nair \& Finkel 2004). It could effectively bind with chromosomal DNA and form the stable Dps-DNA co-crystal. The mutants of Dps also failed to develop starvation-induced resistance to hydrogen peroxide, an agent that can cause oxidative damage to DNA, and show dramatic changes in the pattern of proteins synthesis during starvation in E. coli (Almiron et al. 1992). Such protection can be mediated by the intrinsic properties such as DNA binding, iron sequestration and ferroxidase activity (Calhoun \& Kwon 2011). These properties lend support to the importance of Dps in iron- and hydrogen peroxide-detoxification and acid resistance. Moreover, the prevalence of Dps and Dps-like proteins in bacteria suggests that protection involving DNA and iron sequestration is crucial and widespread in prokaryotes (Calhoun \& Kwon 2011). The Dps has also been identified as a ferritin-like protein, partly because of its ferroxidase activity, or more specifically, its ability to oxidize bound ferrous ions to the ferric state and storing it in the form of $\mathrm{Fe}^{3+}$ ferrihydrite mineral, which can be released after reduction (Calhoun \& Kwon 2011; Nair \& Finkel 2004; Velayudhan et al. 2007). In fact, the primary role of Dps may not be iron storage, but to protect macromolecules from the combined lethality of ferrous ions and $\mathrm{H}_{2} \mathrm{O}_{2}$ (Abdul-Tehrani et al. 1999) and by the fact that Dps strongly prefers $\mathrm{H}_{2} \mathrm{O}_{2}$ over $\mathrm{O}_{2}$ as an oxidant when preparing iron for storage. The catalase activity of Dps seems to be significant in Dps-mediated protection against hydrogen peroxide stress, as Zhao et al. has identified its ability to decompose hydrogen peroxide as a significant method of detoxification in E. coli (Zhao et al. 2002). Altogether, the protective roles of Dps are most likely achieved through various functions associated with the protein-DNA binding and chromosome compaction, metal chelation, ferroxidase activity, regulation of gene expression and a weak catalase activity.

Glyceraldehyde-3-phosphate dehydroge nase (GAPDH) is an enzyme of $\sim 37 \mathrm{kDa}$ that catalyzes the sixth step of glycolysis and thus serves to break down glucose for energy and carbon molecules. In addition to this long established metabolic function, GAPDH has activation, initiation of apoptosis (Tarze et al. 2007). Metabolic adaptation and energy 
598 production are crucial for survival under heavy metal load/stress. This enzyme facilitates the 599 enhanced metabolic needs for survival followed by an enhanced expression of proteins (Vranakis 600 et al. 2014). Additionally, the alterations in the flux of metabolites can create metabolic 601 networks, allowing an organism to go along in a changing environment (Mailloux et al. 2011). 602 The GAPDH and related enzymes were also shown to be involved in the adaptive response to 603 oxidative stress (Oh et al. 2002; Ralser et al. 2007). It can also act as a reversible metabolic 604 switch under oxidative stress. The temporary inactivation of GAPDH by oxidant treatment may 605 re-route the metabolic flux from glycolysis to the pentose-phosphate pathway, allowing the cell 606 to generate more NADPH as an antioxidant cofactor (Ralser et al. 2007).

607

608

\section{Conclusions}

609

610

With respect to the performances of proteomics and bioinformatics tools, this work successfully explores that the DUF326-like domain of Enterobacter cloacae strain EC01

611 (cadmium-tolerant strain) has been found to play imperative roles in detoxification of cadmium

612 stress, possibly by binding to cadmium ions. Such protective effect helps to recover the rate of

613 cell division particularly at the middle- to late-log phase of growth curve in the presence of cadmium ions. This also coincides with the capability to accumulate cadmium ions

615 intracellularly at $6 \mathrm{~h}$. The remarkable binding capability due to the presence of cysteine-rich

616 domains of DUF326-like domain has been observed in the case of EC01 of approximately 2 fold

617 higher than those of the EC07 (cadmium-intolerant strain) and ATCC 13047. Expression of the DUF326-like domain is more pronounced of upto 220 fold higher than the others. Results from the qRT-PCR confirm that the transcription level of DUF326 gene in the EC01 is approximately 14 fold higher than those of the others. This indicates that the cadmium-tolerant strain of EC adapts itself by complexation of cadmium ions by metal-binding proteins rather than using the proteins/enzymes involved in oxidative deterioration, stress responses or outer membrane portion as observed in the case of intolerant or standard strains. Taken altogether, our findings explore the molecular mechanisms of cadmium tolerance in EC and also open up a high possibility of applying either the DUF326-like domain or the EC01 cells as potential tools for cadmium bioremediation in the future.

627

628

629

630

631

632

633

634

\section{Acknowledgements}

\section{References}

Abdul-Tehrani H, Hudson AJ, Chang YS, Timms AR, Hawkins C, Williams JM, Harrison PM, Guest JR, Andrews SC. 1999. Ferritin mutants of Escherichia coli are iron deficient and growth impaired, and fur mutants are iron deficient. Journal of Bacteriology 181:14151428.

Almiron M, Link AJ, Furlong D, Kolter R. 1992. A novel DNA-binding protein with regulatory and protective roles in starved Escherichia coli. Genes \& Development 6:2646-2654.

Andrade LN, Siqueira TES, Martinez R, Darini ALC. 2018. Multidrug-Resistant CTX-M-(15, 9, 2)- and KPC-2-Producing Enterobacter hormaechei and Enterobacter asburiae Isolates 
639

640

641

642

643

644

645

646

647

648

649

650

651

652

653

654

655

656

657

658

659

660

661

662

663

664

665

666

667

668

669

670

671

672

673

674

675

676

677

678

679

680

681

682

683

684

Possessed a Set of Acquired Heavy Metal Tolerance Genes Including a Chromosomal sil Operon (for Acquired Silver Resistance). Frontiers in Microbiology 9:539.

Bakolitsa C, Kumar A, McMullan D, Krishna SS, Miller MD, Carlton D, Najmanovich R, Abdubek P, Astakhova T, Chiu HJ, Clayton T, Deller MC, Duan L, Elias Y, Feuerhelm J, Grant JC, Grzechnik SK, Han GW, Jaroszewski L, Jin KK, Klock HE, Knuth MW, Kozbial P, Marciano D, Morse AT, Nigoghossian E, Okach L, Oommachen S, Paulsen J, Reyes R, Rife CL, Trout CV, van den Bedem H, Weekes D, White A, Xu Q, Hodgson KO, Wooley J, Elsliger MA, Deacon AM, Godzik A, Lesley SA, Wilson IA. 2010. The structure of the first representative of Pfam family PF06475 reveals a new fold with possible involvement in glycolipid metabolism. Acta Crystallographica Section F Structural Biology and Crystallization Communications 66:1211-1217.

Banerjee G, Pandey S, Ray AK, Kumar R. 2015. Bioremediation of Heavy Metals by a Novel Bacterial Strain Enterobacter cloacae and Its Antioxidant Enzyme Activity, Flocculant Production, and Protein Expression in Presence of Lead, Cadmium, and Nickel. Water, air, and soil pollution 226:91.

Banjerdkij P, Vattanaviboon P, Mongkolsuk S. 2005. Exposure to cadmium elevates expression of genes in the OxyR and OhrR regulons and induces cross-resistance to peroxide killing treatment in Xanthomonas campestris. Applied and environmental microbiology 71:18431849.

Bateman A, Coggill P, Finn RD. 2010. DUFs: families in search of function. Acta Crystallographica Section F Structural Biology and Crystallization Communications 66:1148-1152.

Brennan RJ, Schiestl RH. 1996. Cadmium is an inducer of oxidative stress in yeast. Mutation research 356:171-178.

Calhoun LN, Kwon YM. 2011. Structure, function and regulation of the DNA-binding protein Dps and its role in acid and oxidative stress resistance in Escherichia coli: a review. Journal of applied microbiology 110:375-386.

Das D, Lee WS, Grant JC, Chiu HJ, Farr CL, Vance J, Klock HE, Knuth MW, Miller MD, Elsliger MA, Deacon AM, Godzik A, Lesley SA, Kornfeld S, Wilson IA. 2013. Structure and function of the DUF2233 domain in bacteria and in the human mannose 6-phosphate uncovering enzyme. Journal of Biological Chemistry 288:16789-16799.

Egler M, Grosse C, Grass G, Nies DH. 2005. Role of the extracytoplasmic function protein family sigma factor RpoE in metal resistance of Escherichia coli. Journal of Bacteriology 187:2297-2307.

El-Gebali S, Mistry J, Bateman A, Eddy SR, Luciani A, Potter SC, Qureshi M, Richardson LJ, Salazar GA, Smart A, Sonnhammer ELL, Hirsh L, Paladin L, Piovesan D, Tosatto SCE, Finn RD. 2019. The Pfam protein families database in 2019. Nucleic Acids Research 47:D427-D432.

Eletsky A, Michalska K, Houliston S, Zhang Q, Daily MD, Xu X, Cui H, Yee A, Lemak A, Wu B, Garcia M, Burnet MC, Meyer KM, Aryal UK, Sanchez O, Ansong C, Xiao R, Acton TB, Adkins JN, Montelione GT, Joachimiak A, Arrowsmith CH, Savchenko A, Szyperski T, Cort JR. 2014. Structural and functional characterization of DUF1471 domains of Salmonella proteins SrfN, YdgH/SssB, and YahO. PLoS One 9:e101787.

Finn RD, Tate J, Mistry J, Coggill PC, Sammut SJ, Hotz HR, Ceric G, Forslund K, Eddy SR, Sonnhammer EL, Bateman A. 2008. The Pfam protein families database. Nucleic Acids Research 36:D281-288. 
685

686

687

688

689

690

691

692

693

694

695

696

697

698

699

700

701

702

703

704

705

706

707

708

709

710

711

712

713

714

715

716

717

718

719

720

721

722

723

724

725

726

727

728

729

Guo C, Luo C, Guo L, Li M, Guo X, Zhang Y, Wang L, Chen L. 2016. OsSIDP366, a DUF1644 gene, positively regulates responses to drought and salt stresses in rice. Journal of integrative plant biology 58:492-502.

Hernandez A, Mellado RP, Martinez JL. 1998. Metal accumulation and vanadium-induced multidrug resistance by environmental isolates of Escherichia hermannii and Enterobacter cloacae. Applied and environmental microbiology 64:4317-4320.

Higham DP, Sadler PJ, Scawen MD. 1983. Bacterial cadmium-binding proteins. Inorganica Chimica Acta 79:140-142.

Hindupur A, Liu D, Zhao Y, Bellamy HD, White MA, Fox RO. 2006. The crystal structure of the $E$. coli stress protein YciF. Protein science 15:2605-2611.

Isarankura-Na-Ayudhya $\mathrm{P}$, Thippakorn $\mathrm{C}$, Pannengpetch $\mathrm{S}$, Roytrakul S, Isarankura-NaAyudhya C, Bunmee N, Sawangnual S, Prachayasittikul V. 2018. Metal complexation by histidine-rich peptides confers protective roles against cadmium stress in Escherichia coli as revealed by proteomics analysis. PeerJ 6:e5245.

Iyer A, Mody K, Jha B. 2004. Accumulation of hexavalent chromium by an exopolysaccharide producing marine Enterobacter cloaceae. Marine pollution bulletin 49:974-977.

Iyer A, Mody K, Jha B. 2005. Biosorption of heavy metals by a marine bacterium. Marine pollution bulletin 50:340-343.

Jaiswal A, Verma A, Jaiswal P. 2018. Detrimental Effects of Heavy Metals in Soil, Plants, and Aquatic Ecosystems and in Humans. Journal of environmental pathology, toxicology and oncology 37:183-197.

Kawakami T, Kuroki M, Ishii M, Igarashi Y, Arai H. 2010. Differential expression of multiple terminal oxidases for aerobic respiration in Pseudomonas aeruginosa. Environmental microbiology 12:1399-1412.

Khanna N, Kotay SM, Gilbert JJ, Das D. 2011. Improvement of biohydrogen production by Enterobacter cloacae IIT-BT 08 under regulated pH. Journal of Biotechnology 152:9-15.

Lee J, Hiibel SR, Reardon KF, Wood TK. 2010. Identification of stress-related proteins in Escherichia coli using the pollutant cis-dichloroethylene. Journal of applied microbiology 108:2088-2102.

Liu X, Lopez PA, Giessen TW, Giles M, Way JC, Silver PA. 2016. Engineering GeneticallyEncoded Mineralization and Magnetism via Directed Evolution. Scientific reports 6:38019.

Luo C, Guo C, Wang W, Wang L, Chen L. 2014. Overexpression of a new stress-repressive gene OsDSR2 encoding a protein with a DUF966 domain increases salt and simulated drought stress sensitivities and reduces ABA sensitivity in rice. Plant cell reports 33:323-336.

Ma J, Kobayashi DY, Yee N. 2007. Chemical kinetic and molecular genetic study of selenium oxyanion reduction by Enterobacter cloacae SLD1a-1. Environmental science \& technology 41:7795-7801.

Mailloux RJ, Lemire J, Appanna VD. 2011. Metabolic networks to combat oxidative stress in Pseudomonas fluorescens. Antonie Van Leeuwenhoek 99:433-442.

Mashruwala AA, Boyd JM. 2018. Investigating the role(s) of SufT and the domain of unknown function 59 (DUF59) in the maturation of iron-sulfur proteins. Current genetics 64:9-16.

Naik MM, Pandey A, Dubey SK. 2012. Biological characterization of lead-enhanced exopolysaccharide produced by a lead resistant Enterobacter cloacae strain P2B. Biodegradation 23:775-783.

Peer] reviewing PDF | (2019:02:35301:1:1:NEW 31 Mar 2019) 
730

731

732

733

734

735

736

737

738

739

740

741

742

743

744

745

746

747

748

749

750

751

752

753

754

755

756

757

758

759

760

761

762

763

764

765

766

767

768

769

770

771

772

773

774

775

Nair S, Finkel SE. 2004. Dps protects cells against multiple stresses during stationary phase. Journal of Bacteriology 186:4192-4198.

Nies DH. 1992. Resistance to cadmium, cobalt, zinc, and nickel in microbes. Plasmid 27:17-28.

Nies DH. 1999. Microbial heavy-metal resistance. Applied microbiology and biotechnology 51:730-750.

Oh TJ, Kim IG, Park SY, Kim KC, Shim HW. 2002. NAD-dependent malate dehydrogenase protects against oxidative damage in Escherichia coli K-12 through the action of oxaloacetate. Environmental toxicology and pharmacology 11:9-14.

Prasad SS, Aikat K. 2014. Study of bio-degradation and bio-decolourization of azo dye by Enterobacter sp. SXCR. Environmental technology 35:956-965.

Price DJ, Joshi JG. 1983. Ferritin. Binding of beryllium and other divalent metal ions. Journal of Biological Chemistry 258:10873-10880.

Rahman A, Nahar N, Nawani NN, Jass J, Hossain K, Saud ZA, Saha AK, Ghosh S, Olsson B, Mandal A. 2015. Bioremediation of hexavalent chromium (VI) by a soil-borne bacterium, Enterobacter cloacae B2-DHA. Journal of environmental science and health. Part A, Toxic/hazardous substances \& environmental engineering 50:1136-1147.

Ralser M, Wamelink MM, Kowald A, Gerisch B, Heeren G, Struys EA, Klipp E, Jakobs C, Breitenbach M, Lehrach H, Krobitsch S. 2007. Dynamic rerouting of the carbohydrate flux is key to counteracting oxidative stress. Journal of Biology 6:10.

Ren Y, Zhou Z, Guo X, Li Y, Feng L, Wang L. 2010. Complete genome sequence of Enterobacter cloacae subsp. cloacae type strain ATCC 13047. Journal of Bacteriology 192:2463-2464.

Serero A, Lopes J, Nicolas A, Boiteux S. 2008. Yeast genes involved in cadmium tolerance: Identification of DNA replication as a target of cadmium toxicity. DNA Repair (Amst) 7:1262-1275.

Shapiro N, Keasling JD. 1996. The recA gene and cadmium toxicity in Escherichia coli K12. Microbios 86:23-26.

Stohs SJ, Bagchi D. 1995. Oxidative mechanisms in the toxicity of metal ions. Free radical biology \& medicine 18:321-336.

Tarze A, Deniaud A, Le Bras M, Maillier E, Molle D, Larochette N, Zamzami N, Jan G, Kroemer G, Brenner C. 2007. GAPDH, a novel regulator of the pro-apoptotic mitochondrial membrane permeabilization. Oncogene 26:2606-2620.

Tong SM, Chen Y, Ying SH, Feng MG. 2016. Three DUF1996 Proteins Localize in Vacuoles and Function in Fungal Responses to Multiple Stresses and Metal Ions. Scientific reports 6:20566.

Uechi K, Tada T, Shimada K, Nakasone I, Kirikae T, Fujita J. 2018. Emergence of a carbapenem-resistant and colistin-heteroresistant Enterobacter cloacae clinical isolate in Japan. Journal of infection and chemotherapy 25:285-288.

Velayudhan J, Castor M, Richardson A, Main-Hester KL, Fang FC. 2007. The role of ferritins in the physiology of Salmonella enterica sv. Typhimurium: a unique role for ferritin B in iron-sulphur cluster repair and virulence. Molecular microbiology 63:1495-1507.

Vranakis I, Goniotakis I, Psaroulaki A, Sandalakis V, Tselentis Y, Gevaert K, Tsiotis G. 2014. Proteome studies of bacterial antibiotic resistance mechanisms. Journal of Proteomics 97:88-99.

Waisberg M, Joseph P, Hale B, Beyersmann D. 2003. Molecular and cellular mechanisms of cadmium carcinogenesis. Toxicology 192:95-117. 
776 Westermeier R, Scheibe B. 2008. Difference gel electrophoresis based on lys/cys tagging.

$777 \quad$ Methods in molecular biology 424:73-85.

778 Xie H, Buschmann S, Langer JD, Ludwig B, Michel H. 2014. Biochemical and biophysical

779

780

781

782

783

784

785

786

787

788

789 characterization of the two isoforms of cbb3-type cytochrome c oxidase from Pseudomonas stutzeri. Journal of Bacteriology 196:472-482.

Xu C, He S, Liu Y, Zhang W, Lu D. 2017. Bioadsorption and biostabilization of cadmium by Enterobacter cloacae TU. Chemosphere 173:622-629.

Yang C, Cheng Y, Ma X, Zhu Y, Holman HY, Lin Z, Wang C. 2007. Surface-mediated chromate-resistant mechanism of Enterobacter cloacae bacteria investigated by atomic force microscopy. Langmuir 23:4480-4485.

Zhao G, Ceci P, Ilari A, Giangiacomo L, Laue TM, Chiancone E, Chasteen ND. 2002. Iron and hydrogen peroxide detoxification properties of DNA-binding protein from starved cells. A ferritin-like DNA-binding protein of Escherichia coli. Journal of Biological Chemistry 277:27689-27696.

790

791 


\section{Table $\mathbf{1}$ (on next page)}

Genus and species identification of 9 environmental isolates and ATCC strain of $E$. cloacae by MALDI-TOF mass spectrometry 
1 Table 1 Genus and species identification of 9 environmental isolates and ATCC strain of $E$.

2 cloacae by MALDI-TOF mass spectrometry

3

\begin{tabular}{|c|c|c|c|c|c|}
\hline \multirow[b]{2}{*}{ No. } & \multirow[b]{2}{*}{ Name } & \multicolumn{4}{|c|}{ MALDI-TOF/MS } \\
\hline & & $\begin{array}{c}\text { Organism } \\
\text { (best match) }\end{array}$ & $\begin{array}{l}\text { Score } \\
\text { Value }\end{array}$ & $\begin{array}{c}\text { Organism } \\
\text { (second best } \\
\text { match) }\end{array}$ & $\begin{array}{l}\text { Score } \\
\text { Value }\end{array}$ \\
\hline 1 & E. cloacae 01 & $\frac{\text { Enterobacter }}{\text { cloacae }}$ & 2.013 & $\frac{\text { Enterobacter }}{\text { cloacae }}$ & 2.002 \\
\hline 2 & E. cloacae 02 & $\frac{\text { Enterobacter }}{\text { cloacae }}$ & 2.122 & $\frac{\text { Enterobacter }}{\underline{\text { kobei }}}$ & $\underline{2.099}$ \\
\hline 3 & E. cloacae 05 & $\frac{\text { Enterobacter }}{\text { cloacae }}$ & 2.072 & $\frac{\text { Enterobacter }}{\text { cloacae }}$ & $\underline{2.011}$ \\
\hline 4 & E. cloacae 06 & $\frac{\text { Enterobacter }}{\text { cloacae }}$ & $\underline{2.177}$ & $\frac{\text { Enterobacter }}{\text { cloacae }}$ & 2.004 \\
\hline 5 & E. cloacae 07 & $\frac{\text { Enterobacter }}{\text { cloacae }}$ & 2.255 & $\frac{\text { Enterobacter }}{\text { cloacae }}$ & 2.172 \\
\hline 6 & E. cloacae 08 & $\frac{\text { Enterobacter }}{\text { cloacae }}$ & $\underline{2.142}$ & $\frac{\text { Enterobacter }}{\text { cloacae }}$ & $\underline{2.068}$ \\
\hline 7 & E. cloacae 09 & $\frac{\text { Enterobacter }}{\text { cloacae }}$ & 2.173 & $\frac{\text { Enterobacter }}{\text { cloacae }}$ & 2.046 \\
\hline 8 & E. cloacae 10 & $\frac{\text { Enterobacter }}{\text { cloacae }}$ & 2.099 & $\frac{\text { Enterobacter }}{\text { cloacae }}$ & \\
\hline 9 & E. cloacae 11 & $\frac{\text { Enterobacter }}{\text { cloacae }}$ & 2.08 & $\frac{\text { Enterobacter }}{\underline{\text { kobei }}}$ & $\underline{2.066}$ \\
\hline 10 & ATCC 13047 & $\frac{\text { Enterobacter }}{\text { cloacae }}$ & 2.001 & $\frac{\text { Enterobacter }}{\text { cloacae }}$ & \\
\hline
\end{tabular}

Note Meaning of score values derived from MALDI/TOF mass spectrometry are as follows:

- Values in the range of 2.300-3.000 denote the highly probable species identification (represented in green)

- Values in the range of 2.000-2.299 denote the secure genus identification, probable species identification (represented in green)

- Values in the range of 1.700-1.999 denote the secure genus identification (represented in yellow)

- Values in the range of 0.000-1.699 denote the unreliable identification (represented in red) 


\section{Table 2 (on next page)}

The minimum inhibitory concentrations (MICs) of cadmium, zinc and copper ions of 9 environmental strains and ATCC 13047 strain of E. cloacae 
1 Table 2 The minimum inhibitory concentrations (MICs) of cadmium, zinc and copper ions of 9

2 environmental strains and ATCC 13047 strain of E. cloacae

3

\begin{tabular}{ccccc}
\hline \multirow{2}{*}{ No. } & \multirow{2}{*}{ Name } & \multicolumn{3}{c}{ Minimal Inhibitory Concentration (MIC) test } \\
\cline { 3 - 5 } & & $\mathrm{Cd}^{2+}(\mathrm{mM})$ & $\mathrm{Zn}^{2+}(\mathrm{mM})$ & $\mathrm{Cu}^{2+}(\mathrm{mM})$ \\
\hline 1 & ATCC 13047 & 1.6 & 3.2 & 8 \\
2 & E. cloacae 01 & 1.6 & 3.2 & 8 \\
3 & E. cloacae 02 & 0.8 & 1.6 & 8 \\
4 & E. cloacae 05 & 0.8 & 1.6 & 8 \\
5 & E. cloacae 06 & 0.8 & 1.6 & 4 \\
6 & E. cloacae 07 & 0.4 & 3.2 & 8 \\
7 & E. cloacae 08 & 1.6 & 1.6 & 4 \\
8 & E. cloacae 09 & 0.8 & 1.6 & 8 \\
9 & E. cloacae 10 & 0.8 & 1.6 & 8 \\
10 & E. cloacae 11 & 0.8 & 1.6 & 4 \\
\hline
\end{tabular}

4 


\section{Table 3(on next page)}

Differentially expressed proteins of $E$. cloacae represented as fold changes in response to cadmium treatment. Proteins were identified by QTOF mass spectrometry. 
Table 3 Differentially expressed proteins of E. cloacae represented as fold changes in response to cadmium treatment. Proteins were identified by QTOF mass spectrometry.

\begin{tabular}{|c|c|c|c|c|c|c|c|c|c|c|}
\hline $\begin{array}{l}\text { Spot } \\
\text { no. }\end{array}$ & Accession no. & Protein names & $\begin{array}{c}\text { Fold change ATCC } \\
13047+C d\end{array}$ & $\begin{array}{l}\text { Fold change } \\
\text { EC01 + Cd }\end{array}$ & $\begin{array}{l}\text { Fold change } \\
\text { EC07 + Cd }\end{array}$ & Anova & M.W. & $p \mathbf{I}$ & Score & $\begin{array}{c}\% \text { protein } \\
\text { seq. coverage }\end{array}$ \\
\hline 1 & KGB06270.1 & catalase HPII & -1.07 & 1.76 & -1.11 & $3.42 \mathrm{E}-03$ & 83514 & 5.63 & 331 & 14 \\
\hline 2 & KGB06270.1| & catalase HPII & 2.23 & 2.33 & -1.04 & $2.89 \mathrm{E}-04$ & 83514 & 5.63 & 314 & 7 \\
\hline 3 & KGB06270.1 & catalase HPII & -1.15 & 1.34 & 1.31 & 5.33E-01 & 83514 & 5.63 & 1587 & 16 \\
\hline 4 & KGB06270.1| & catalase HPII & 1.57 & 1.14 & 1.21 & $1.02 \mathrm{E}-05$ & 83514 & 5.63 & 1396 & 22 \\
\hline 5 & KJC00120.1| & hydroperoxidase & -1.56 & -1.59 & -2.04 & $1.70 \mathrm{E}-07$ & 83488 & 5.66 & 298 & 13 \\
\hline 6 & CZY07068.1| & hydroperoxidase II & Undetectable & -1.85 & Undetectable & 4.33E-02 & 83493 & 5.76 & 151 & 7 \\
\hline 7 & SAG51425.1| & hydroperoxidase II & Undetectable & -1.06 & Undetectable & $1.52 \mathrm{E}-02$ & 83473 & 5.61 & 1471 & 24 \\
\hline 8 & KJC00120.1| & hydroperoxidase II & Undetectable & Undetectable & -1.87 & $2.82 \mathrm{E}-02$ & 83488 & 5.66 & 791 & 18 \\
\hline 9 & KJX08087.1| & succinate-semialdehyde dehydrogenase & 1.22 & -1.06 & -1.13 & $7.38 \mathrm{E}-10$ & 49930 & 5.71 & 516 & 25 \\
\hline 10 & KTI00918.1| & dihydrolipoamide dehydrogenase & -1.03 & 1.46 & -1.05 & $1.66 \mathrm{E}-06$ & 50867 & 5.79 & 302 & 16 \\
\hline 11 & KJC00120.1| & hydroperoxidase & Undetectable & Undetectable & 3.88 & $3.11 \mathrm{E}-04$ & 83488 & 5.66 & 580 & 20 \\
\hline 12 & ADF60390.1| & chaperone protein DnaK & -1.38 & -1.06 & -1.98 & $1.39 \mathrm{E}-01$ & 69092 & 4.82 & 120 & 13 \\
\hline 13 & SAB00249.1 & 30 S ribosomal protein $\mathrm{S} 1$ & -2.14 & -1.28 & -2.04 & $1.40 \mathrm{E}-01$ & 61289 & 4.89 & 134 & 14 \\
\hline 14 & KLG03309.1| & peroxiredoxin OsmC & -7.07 & -2.44 & -1.15 & $6.58 \mathrm{E}-03$ & 15005 & 6.04 & 217 & 52 \\
\hline 15 & KGB03490.1 & DNA protection during starvation protein & -7.51 & -3.74 & -1.01 & $1.39 \mathrm{E}-02$ & 18720 & 5.94 & 1022 & 76 \\
\hline 16 & KPU05892.1 & superoxide dismutase & 1.26 & -1.16 & -1.23 & $2.94 \mathrm{E}-02$ & 17768 & 6.43 & 766 & 33 \\
\hline 17 & ADF61100.1 & type VI secretion system secreted protein Hcp & Not analysis & Not analysis & Not analysis & Not analysis & 16996 & 5.76 & 432 & 40 \\
\hline 18 & SAH00153.1 & OsmC family protein & Undetectable & Undetectable & -1.91 & 5.04E-08 & 15149 & 5.74 & 156 & 52 \\
\hline 19 & SAG00330.1 & DNA protection during starvation protein & Undetectable & Undetectable & 2.01 & $4.55 \mathrm{E}-05$ & 18677 & 5.72 & 819 & 36 \\
\hline 20 & SAG00330.1 & DNA protection during starvation protein & Undetectable & Undetectable & -5.1 & 4.68E-07 & 18677 & 5.72 & 506 & 38 \\
\hline 21 & KJQ00352.1 & 50 S ribosomal protein L21 & -1.33 & -1.09 & 1.1 & $6.97 \mathrm{E}-06$ & 11543 & 9.85 & 58 & 7 \\
\hline 22 & EUM00092.1| & Universal stress protein A & -1.84 & -1.15 & -1.38 & $7.28 \mathrm{E}-05$ & 16200 & 4.98 & 53 & 23 \\
\hline 23 & AQT90079.1| & outer membrane protein OmpX & -1.28 & -1.22 & 1.3 & $1.35 \mathrm{E}-07$ & 18654 & 6.23 & 1064 & 22 \\
\hline 24 & SAF00184.1 & protein $\mathrm{YciE}$ & Undetectable & Undetectable & -1.74 & $2.68 \mathrm{E}-04$ & 19036 & 4.85 & 173 & 28 \\
\hline 25 & SAF00211.1 & protein $Y c i F$ & Undetectable & Undetectable & -1.06 & 4.32E-09 & 18313 & 5.04 & 1838 & 29 \\
\hline 26 & OUF00075.1| & osmotically-inducible protein $\mathrm{Y}$ & Not analysis & Not analysis & 1.1 & $3.72 \mathrm{E}-03$ & 21426 & 6.17 & 1181 & 35 \\
\hline 27 & CZX11689.1 & protein $\mathrm{YciF}$ & Undetectable & Undetectable & 2.45 & $3.65 \mathrm{E}-05$ & 18325 & 4.95 & 535 & 60 \\
\hline 28 & KPU03204.1| & heat-shock protein Hsp20 & 1.3 & 2.39 & 1.29 & $6.21 \mathrm{E}-05$ & 21493 & 5.32 & 687 & 48 \\
\hline 29 & SAD00058.1 & TrpR binding protein WrbA & -1.31 & -1.01 & 1.41 & $8.72 \mathrm{E}-10$ & 20847 & 5.78 & 255 & 25 \\
\hline 30 & KJX08128.1| & periplasmic protein & -1.04 & -1.78 & -1.75 & $1.69 \mathrm{E}-05$ & 21374 & 8.63 & 1272 & 54 \\
\hline 31 & CZW02624.1| & $\begin{array}{l}\text { periplasmic binding protein/LacI transcriptional } \\
\text { regulator }\end{array}$ & -2.05 & 1.011 & -1.34 & $6.04 \mathrm{E}-09$ & 35617 & 5.88 & 1576 & 53 \\
\hline 32 & OUF11927.1| & malate dehydrogenase & 1.32 & 1.43 & 1.05 & 1.17E-09 & 32673 & 5.9 & 1086 & 42 \\
\hline 33 & CZX00043.1 & 2,5-diketo-D-gluconate reductase A & -1.09 & 1.21 & -1.07 & $1.46 \mathrm{E}-02$ & 30934 & 5.49 & 219 & 54 \\
\hline 34 & SAD00983.1 & $\begin{array}{l}\text { cationic amino acid } \mathrm{ABC} \text { transporter substrate- } \\
\text { binding protein }\end{array}$ & -1.37 & -1.27 & -1.45 & 4.27E-01 & 28179 & 7.6 & 333 & 23 \\
\hline 35 & KGB04009.1| & $\begin{array}{l}\text { bacterial extracellular solute-bindings, } 3 \text { family } \\
\text { protein }\end{array}$ & -1.49 & -1.91 & 1.14 & $6.37 \mathrm{E}-04$ & 33362 & 8.8 & 565 & 42 \\
\hline 36 & KJC00085.1| & glyceraldehyde-3-phosphate dehydrogenase & 1.37 & 1.45 & 1.06 & $1.32 \mathrm{E}-02$ & 35648 & 6.61 & 585 & 42 \\
\hline 37 & SAJ08363.1 & glyceraldehyde-3-phosphate dehydrogenase & 1.62 & 1.72 & 1.07 & 5.94E-06 & 35650 & 6.61 & 189 & 17 \\
\hline 38 & ADF61881.1| & superoxide dismutase & 1.59 & -1.05 & 1.17 & $1.01 \mathrm{E}-02$ & 21457 & 5.54 & 46 & 17 \\
\hline
\end{tabular}




\begin{tabular}{|c|c|c|c|c|c|c|c|c|c|c|}
\hline $\begin{array}{c}\text { Spot } \\
\text { no. }\end{array}$ & Accession no. & Protein names & $\begin{array}{l}\text { Fold change ATCC } \\
13047+\text { Cd }\end{array}$ & $\begin{array}{l}\text { Fold change } \\
\text { EC01 + Cd }\end{array}$ & $\begin{array}{l}\text { Fold change } \\
\text { EC07+Cd }\end{array}$ & Anova & M.W. & $p \mathbf{I}$ & Score & $\begin{array}{c}\text { \% protein } \\
\text { seq. coverage }\end{array}$ \\
\hline 39 & SAD00058.1| & TrpR binding protein WrbA & -1.35 & -1.7 & -1.06 & $5.17 \mathrm{E}-02$ & 20847 & 5.78 & 1160 & 35 \\
\hline 40 & KTI00016.1| & superoxide dismutase & -1.08 & -1.05 & 1.19 & 4.00E-01 & 22995 & 6.23 & 204 & 13 \\
\hline 41 & KTI01411.1| & hypothetical protein ASV14_00320 & -1.21 & -1.17 & 1.17 & $2.53 \mathrm{E}-07$ & 37677 & 5.33 & 1254 & 47 \\
\hline 42 & CZW04458.1| & outer membrane protein $\mathrm{A}$ & -1.14 & -1.43 & 1.24 & 4.62E-08 & 37577 & 5.2 & 1791 & 48 \\
\hline 43 & KJX05875.1| & porin [Enterobacter cloacae subsp. cloacae] & -1.36 & -1.26 & 1.27 & $5.81 \mathrm{E}-09$ & 39231 & 4.58 & 493 & 32 \\
\hline 44 & $5 \mathrm{FVN} \mid \mathrm{A}$ & $\begin{array}{l}\text { Chain A, X-ray Crystal Structure of Enterobacter } \\
\text { cloacae Ompe } 36 \text { Porin }\end{array}$ & -1.28 & 1.06 & 1.09 & $2.01 \mathrm{E}-07$ & 37857 & 4.39 & 3805 & 35 \\
\hline 45 & SAF58867.1| & OmpC porin & -1.24 & -2.06 & 1.38 & $8.59 \mathrm{E}-07$ & 39850 & 4.44 & 573 & 35 \\
\hline 46 & KJQ00573.1| & fructose-bisphosphate aldolase & 1.5 & 1.6 & -1.18 & $3.50 \mathrm{E}-03$ & 39384 & 5.52 & 124 & 23 \\
\hline 47 & SAH00347.1| & alcohol dehydrogenase & -1.25 & 1 & -1.15 & $2.21 \mathrm{E}-05$ & 35832 & 5.7 & 1725 & 60 \\
\hline 48 & KPU01695.1| & elongation factor $\mathrm{Tu}$ & -1.57 & -1.55 & 1.12 & $2.09 \mathrm{E}-03$ & 43460 & 5.25 & 494 & 27 \\
\hline 49 & KPU01695.1 & elongation factor $\mathrm{Tu}$ & -1.59 & -1.17 & -1.46 & $4.33 \mathrm{E}-02$ & 43460 & 5.25 & 481 & 29 \\
\hline 50 & CZW60501.1 & isocitrate dehydrogenase & -1.36 & 1.17 & -1.25 & $9.02 \mathrm{E}-03$ & 46145 & 5.14 & 127 & 23 \\
\hline 51 & CZW60501.1| & isocitrate dehydrogenase & -1.18 & 1.18 & -1.51 & $1.49 \mathrm{E}-08$ & 46145 & 5.14 & 79 & 9 \\
\hline 52 & SAH00247.1| & enolase & 1.19 & 1.56 & -1.35 & $1.65 \mathrm{E}-03$ & 45632 & 5.19 & 85 & 10 \\
\hline 53 & SAI00778.1| & elongation factor $\mathrm{Tu}$ & -1.39 & 1.25 & -1.8 & $3.38 \mathrm{E}-02$ & 43444 & 5.25 & 673 & 33 \\
\hline 54 & WP_075208257.1| & translation elongation factor $\mathrm{Tu}$ & -1.37 & 1.04 & -1.84 & $2.35 \mathrm{E}-05$ & 40036 & 5.01 & 495 & 40 \\
\hline 55 & KJJ00122.1| & molecular chaperone GroEL & 2.29 & 2.51 & -1.29 & 7.48E-06 & 57205 & 4.88 & 800 & 38 \\
\hline 56 & KPU06091.1 & molecular chaperone GroEL & 1.32 & 1.33 & -1.09 & $3.85 \mathrm{E}-06$ & 57209 & 4.85 & 484 & 36 \\
\hline 57 & SAB11354.1| & Domain of Uncharacterised Function (DUF326) & Undetectable & 1.35 & Undetectable & $9.38 \mathrm{E}-11$ & 13306 & 5.27 & 3402 & 66 \\
\hline 58 & CZV11460.1 & Putative hydrolase & 1.59 & -1.1 & -1.24 & $1.98 \mathrm{E}-02$ & 72227 & 5.28 & 213 & 10 \\
\hline 59 & KPU06091.1| & molecular chaperone GroEL & 1.85 & 1.36 & 1.09 & $1.56 \mathrm{E}-02$ & 57209 & 4.85 & 800 & 27 \\
\hline 60 & KJJ00126.1 & aspartate ammonia-lyase & -1.59 & 1.55 & -1.37 & $9.13 \mathrm{E}-06$ & 52776 & 5.05 & 140 & 23 \\
\hline 61 & SAB00249.1| & $30 \mathrm{~S}$ ribosomal protein $\mathrm{S} 1$ & -4.92 & -2.24 & 1.03 & $2.31 \mathrm{E}-03$ & 61289 & 4.89 & 139 & 10 \\
\hline 62 & SAJ00217.1| & F0F1 ATP synthase subunit beta & 1.29 & 1.29 & -1.14 & $2.46 \mathrm{E}-04$ & 50268 & 4.89 & 305 & 19 \\
\hline 63 & CZY00919.1 & maltoporin & -1.25 & 1.08 & 1.21 & $1.38 \mathrm{E}-04$ & 48457 & 4.79 & 471 & 27 \\
\hline 64 & SAB00172.1| & Tellurium resistance protein TerE & -1.75 & -1.66 & -1.27 & $1.60 \mathrm{E}-02$ & 20437 & 4.69 & 688 & 30 \\
\hline 65 & SAB00191.1| & Tellurium resistance protein TerD & -1.1 & -1.61 & -1.28 & $3.66 \mathrm{E}-05$ & 20573 & 4.64 & 1803 & 36 \\
\hline 66 & KTI00836.1| & molecular chaperone DnaK & -1.73 & -1.61 & 1.22 & $4.85 \mathrm{E}-04$ & 69092 & 4.82 & 473 & 9 \\
\hline 67 & WP 004144995.1] & MULTISPECIES: ATP synthase subunit alpha & 2.98 & 1.24 & -1.19 & 4.42E-03 & 55363 & 5.73 & 99 & 19 \\
\hline 68 & CZZ̄00122.1] & glucose-specific PTS system component & Undetectable & Undetectable & 2.16 & $1.38 \mathrm{E}-01$ & 18313 & 5.04 & 104 & 7 \\
\hline 69 & CZZ00122.11 & glucose-specific PTS system component & -3.03 & -1.71 & -1.61 & $6.63 \mathrm{E}-05$ & 18222 & 4.73 & 660 & 27 \\
\hline 70 & KGZ01983.1| & $\begin{array}{l}\text { chemical-damaging agent resistance protein } \mathrm{C} \text { note } \\
\text { like to terD domain protein and Tellurium } \\
\text { resistance protein TerE }\end{array}$ & -3.64 & -1.5 & 1.02 & $1.71 \mathrm{E}-01$ & 20463 & 4.69 & 392 & 39 \\
\hline 71 & SAF00152.1| & manganese catalase & Undetectable & Undetectable & 1.13 & $3.21 \mathrm{E}-05$ & 31431 & 4.8 & 338 & 20 \\
\hline 72 & KJJ00123.1| & molecular chaperone GroES & -1.05 & 1.11 & 1.27 & $1.02 \mathrm{E}-05$ & 10354 & 5.38 & 83 & 27 \\
\hline 73 & KJJ00123.1| & molecular chaperone GroES & Undetectable & -1.13 & 1.29 & $4.92 \mathrm{E}-03$ & 10354 & 5.38 & 70 & 14 \\
\hline 74 & KJJ00123.1| & molecular chaperone GroES & -1.21 & -1.32 & -1.25 & $1.44 \mathrm{E}-01$ & 10354 & 5.38 & 555 & 58 \\
\hline 75 & $\begin{array}{l}\text { Q84FI1.1|DPS_EN } \\
\text { TCL }\end{array}$ & $\begin{array}{l}\text { RecName: Full=DNA protection during starvation } \\
\text { protein }\end{array}$ & Undetectable & Undetectable & -1.21 & $8.29 \mathrm{E}-07$ & 18691 & 5.95 & 133 & 23 \\
\hline 76 & SAC00082.11 & LysM domain/BON superfamily protein & -3.09 & -1.52 & Undetectable & $5.26 \mathrm{E}-06$ & 15895 & 5.4 & 155 & 24 \\
\hline 77 & KJC00085.1| & glyceraldehyde-3-phosphate dehydrogenase & -3.26 & -2.55 & Undetectable & 3.38E-07 & 35648 & 6.61 & 227 & 16 \\
\hline
\end{tabular}




\begin{tabular}{|c|c|c|c|c|c|c|c|c|c|c|}
\hline $\begin{array}{c}\text { Spot } \\
\text { no. }\end{array}$ & Accession no. & Protein names & $\begin{array}{c}\text { Fold change ATCC } \\
13047+\text { Cd }\end{array}$ & $\begin{array}{l}\text { Fold change } \\
\text { EC01 + Cd }\end{array}$ & $\begin{array}{l}\text { Fold change } \\
\text { EC07 + Cd }\end{array}$ & Anova & M.W. & $p \mathbf{I}$ & Score & $\begin{array}{c}\text { \% protein } \\
\text { seq. coverage }\end{array}$ \\
\hline 78 & KPU04452.1| & ecotin & -1.08 & -1.56 & Undetectable & 1.79E-08 & 19034 & 8.35 & 208 & 28 \\
\hline 79 & ESM17978.1| & glutamine-binding periplasmic protein & -1.03 & 2.38 & 1.8 & $1.04 \mathrm{E}-02$ & 26950 & 8.91 & 130 & 15 \\
\hline 80 & KGB04009.1| & $\begin{array}{l}\text { bacterial extracellular solute-bindings, } 3 \text { family } \\
\text { protein }\end{array}$ & Not analysis & Not analysis & Not analysis & Not analysis & 33362 & 8.8 & 884 & 19 \\
\hline
\end{tabular}


Table 4 (on next page)

Regulation of major responsive proteins found in EC01 (cut-off at 1.3 fold) 
1 Table 4 Regulation of major responsive proteins found in EC01 (cut-off at 1.3 fold)

\begin{tabular}{|c|c|c|c|c|c|}
\hline $\begin{array}{l}\text { Spot } \\
\text { no. }\end{array}$ & Accession no. & Protein names & $\begin{array}{c}\text { Ratio of } \\
\text { 01-Cd/07-Cd }\end{array}$ & $\begin{array}{c}\text { Ratio of } \\
\text { 01-Cd/01-control } \\
\end{array}$ & Anova \\
\hline 57 & SAB11354.1| & $\begin{array}{l}\text { Domain of Uncharacterized } \\
\text { Function (DUF326) }\end{array}$ & +220.92 & +1.35 & $9.38 \mathrm{E}-11$ \\
\hline 6 & CZY07068.1 & hydroperoxidase II & +42.29 & U.D. & 4.33E-02 \\
\hline 7 & SAG51425.1 & hydroperoxidase II & +21.28 & U.D. & $1.52 \mathrm{E}-02$ \\
\hline 30 & KJX08128.1 & periplasmic protein & +14.29 & -1.78 & $1.69 \mathrm{E}-05$ \\
\hline 16 & KPU05892.1| & superoxide dismutase & +8.14 & -1.16 & $2.94 \mathrm{E}-02$ \\
\hline 32 & OUF11927.1| & malate dehydrogenase & +7.45 & +1.43 & 1.17E-09 \\
\hline 23 & AQT90079.1| & $\begin{array}{l}\text { outer membrane protein } \\
\text { OmpX }\end{array}$ & +6.98 & -1.22 & $1.35 \mathrm{E}-07$ \\
\hline 41 & KTI01411.1| & $\begin{array}{l}\text { hypothetical protein } \\
\text { ASV14_00320 }\end{array}$ & +6.63 & -1.17 & $2.53 \mathrm{E}-07$ \\
\hline 38 & ADF61881.1| & superoxide dismutase & +5.94 & -1.05 & $1.01 \mathrm{E}-02$ \\
\hline 2 & KGB06270.1 & catalase HPII & +5.02 & +2.33 & 2.89E-04 \\
\hline 56 & KPU06091.1 & molecular chaperone GroEL & +4.59 & +1.33 & $3.85 \mathrm{E}-06$ \\
\hline 1 & KGB06270.1 & catalase HPII & +3.41 & +1.76 & $3.42 \mathrm{E}-03$ \\
\hline 15 & KGB03490.1| & $\begin{array}{l}\text { DNA protection during } \\
\text { starvation protein }\end{array}$ & +3.00 & -3.74 & $1.39 \mathrm{E}-02$ \\
\hline 14 & KLG03309.1| & peroxiredoxin OsmC & +2.74 & -2.44 & $6.58 \mathrm{E}-03$ \\
\hline 59 & KPU06091.1| & molecular chaperone GroEL & +2.21 & +1.36 & $1.56 \mathrm{E}-02$ \\
\hline 76 & SAC00082.1| & $\begin{array}{l}\text { LysM domain/BON } \\
\text { superfamily protein }\end{array}$ & +2.07 & -1.52 & $5.26 \mathrm{E}-06$ \\
\hline 65 & SAB00191.1| & $\begin{array}{l}\text { Tellurium resistance protein } \\
\text { TerD }\end{array}$ & +1.90 & -1.61 & $3.66 \mathrm{E}-05$ \\
\hline 78 & KPU04452.1 & ecotin & +1.87 & -1.56 & $1.79 \mathrm{E}-08$ \\
\hline 77 & KJC00085.1| & $\begin{array}{l}\text { glyceraldehyde-3-phosphate } \\
\text { dehydrogenase }\end{array}$ & +1.71 & -2.55 & $3.38 \mathrm{E}-07$ \\
\hline 70 & KGZ01983.1| & $\begin{array}{l}\text { chemical-damaging agent } \\
\text { resistance protein } \mathrm{C} \text { note like } \\
\text { to terD domain protein and } \\
\text { Tellurium resistance protein } \\
\text { TerE }\end{array}$ & +1.62 & -1.50 & $1.71 \mathrm{E}-01$ \\
\hline 48 & KPU01695.1 & elongation factor $\mathrm{Tu}$ & +1.47 & -1.55 & 2.09E-03 \\
\hline 35 & KGB04009.1| & $\begin{array}{l}\text { bacterial extracellular solute- } \\
\text { bindings, } 3 \text { family protein }\end{array}$ & +1.38 & -1.91 & $6.37 \mathrm{E}-04$ \\
\hline
\end{tabular}

2 


\section{Table 5 (on next page)}

Regulation of major responsive proteins found in EC07 (cut-off at 1.3 fold) 
1 Table 5 Regulation of major responsive proteins found in EC07 (cut-off at 1.3 fold)

\begin{tabular}{|c|c|c|c|c|c|}
\hline $\begin{array}{l}\text { Spot } \\
\text { no. }\end{array}$ & Accession no. & Protein names & $\begin{array}{c}\text { Ratio of } \\
\text { 07-Cd/01-Cd }\end{array}$ & $\begin{array}{c}\text { Ratio of } \\
\text { 07-Cd/07-control }\end{array}$ & Anova \\
\hline 25 & SAF00211.1| & Protein YciF & 84.7 & -1.06 & $4.32 \mathrm{E}-09$ \\
\hline 45 & SAF58867.1| & OmpC porin & 53.2 & 1.38 & $8.59 \mathrm{E}-07$ \\
\hline 71 & SAF00152.1 & Manganese catalase & 51.7 & 1.13 & $3.21 \mathrm{E}-05$ \\
\hline 26 & OUF00075.1| & $\begin{array}{l}\text { Osmotically-inducible protein } \\
\text { Y }\end{array}$ & 42.8 & 1.10 & $3.72 \mathrm{E}-03$ \\
\hline 75 & $\begin{array}{l}\text { Q84FI1.1|DPS } \\
\text { ENTCL }\end{array}$ & $\begin{array}{l}\text { DNA protection during } \\
\text { starvation protein }\end{array}$ & 32.7 & -1.21 & 8.29E-07 \\
\hline 18 & SAH00153.1| & OsmC family protein & 29.2 & -1.91 & 5.04E-08 \\
\hline 8 & KJC00120.1 & hydroperoxidase II & 24.2 & -1.87 & $2.82 \mathrm{E}-02$ \\
\hline 27 & CZX11689.1| & Protein YciF & 19.8 & 2.45 & $3.65 \mathrm{E}-05$ \\
\hline 4 & KGB06270.1 & Catalase HPII & 18.5 & 1.21 & $1.02 \mathrm{E}-05$ \\
\hline 11 & KJC00120.1 & Hydroperoxidase & 13.9 & 3.88 & $3.11 \mathrm{E}-04$ \\
\hline 19 & SAG00330.1| & $\begin{array}{l}\text { DNA protection during } \\
\text { starvation protein }\end{array}$ & 12.3 & 2.01 & $4.55 \mathrm{E}-05$ \\
\hline 47 & SAH00347.1| & Alcohol dehydrogenase & 11.7 & -1.15 & $2.21 \mathrm{E}-05$ \\
\hline 43 & KJX05875.1| & Porin & 10.1 & 1.27 & 5.81E-09 \\
\hline 20 & SAG00330.1| & $\begin{array}{l}\text { DNA protection during } \\
\text { starvation protein }\end{array}$ & 9.9 & -5.1 & $4.68 \mathrm{E}-07$ \\
\hline 42 & CZW04458.1 & Outer membrane protein $\mathrm{A}$ & 6.6 & 1.24 & $4.62 \mathrm{E}-08$ \\
\hline 51 & CZW60501.1 & Isocitrate dehydrogenase & 5.4 & -1.51 & $1.49 \mathrm{E}-08$ \\
\hline 5 & KJC00120.1 & Hydroperoxidase & 3.7 & -2.04 & $1.70 \mathrm{E}-07$ \\
\hline 54 & $\begin{array}{c}\text { WP_07520825 } \\
7.1 \mid\end{array}$ & $\begin{array}{l}\text { Translation elongation factor } \\
\mathrm{Tu}\end{array}$ & 3.6 & -1.84 & $2.35 \mathrm{E}-05$ \\
\hline 9 & KJX08087.1| & $\begin{array}{l}\text { Succinate-semialdehyde } \\
\text { dehydrogenase }\end{array}$ & 3.4 & -1.13 & $7.38 \mathrm{E}-10$ \\
\hline 60 & KJJ00126.1 & Aspartate ammonia-lyase & 3.4 & -1.37 & $9.13 \mathrm{E}-06$ \\
\hline 55 & KJJ00122.1 & Molecular chaperone GroEL & 3.1 & -1.29 & $7.48 \mathrm{E}-06$ \\
\hline 72 & KJJ00123.1 & Molecular chaperone GroES & 2.8 & 1.27 & $1.02 \mathrm{E}-05$ \\
\hline 44 & $5 \mathrm{FVN} \mid \mathrm{A}$ & $\begin{array}{l}\text { Chain A, X-ray Crystal } \\
\text { Structure Of Enterobacter } \\
\text { Cloacae Ompe36 Porin }\end{array}$ & 2.6 & 1.09 & $2.01 \mathrm{E}-07$ \\
\hline 24 & SAF00184.1| & Protein YciE & 2.4 & -1.74 & $2.68 \mathrm{E}-04$ \\
\hline 29 & SAD00058.1| & TrpR binding protein WrbA & 2.0 & 1.41 & $8.72 \mathrm{E}-10$ \\
\hline 46 & KJQ00573.1| & $\begin{array}{l}\text { Fructose-bisphosphate } \\
\text { aldolase }\end{array}$ & 2.0 & -1.18 & $3.50 \mathrm{E}-03$ \\
\hline 10 & KTI00918.1| & $\begin{array}{l}\text { Dihydrolipoamide } \\
\text { dehydrogenase }\end{array}$ & 2.0 & -1.05 & $1.66 \mathrm{E}-06$ \\
\hline 61 & SAB00249.1 & 30S ribosomal protein S1 & 1.9 & 1.03 & $2.31 \mathrm{E}-03$ \\
\hline 73 & KJJ00123.1 & Molecular chaperone GroES & 1.8 & 1.29 & 4.92E-03 \\
\hline 31 & CZW02624.1| & $\begin{array}{l}\text { Periplasmic binding } \\
\text { protein/LacI transcriptional } \\
\text { regulator }\end{array}$ & 1.7 & -1.34 & $6.04 \mathrm{E}-09$ \\
\hline 67 & $\begin{array}{c}\text { WP_00414499 } \\
5.1\end{array}$ & $\begin{array}{l}\text { MULTISPECIES: ATP } \\
\text { synthase subunit alpha }\end{array}$ & 1.6 & -1.19 & 4.42E-03 \\
\hline 62 & SAJ00217.1| & $\begin{array}{l}\text { F0F1 ATP synthase subunit } \\
\text { beta }\end{array}$ & 1.6 & -1.14 & $2.46 \mathrm{E}-04$ \\
\hline 52 & SAH00247.1| & Enolase & 1.5 & -1.35 & $1.65 \mathrm{E}-03$ \\
\hline 33 & CZX00043.1| & $\begin{array}{l}\text { 2,5-diketo-D-gluconate } \\
\text { reductase A }\end{array}$ & 1.4 & -1.07 & $1.46 \mathrm{E}-02$ \\
\hline 49 & KPU01695.1| & Elongation factor $\mathrm{Tu}$ & 1.4 & -1.46 & $4.33 \mathrm{E}-02$ \\
\hline
\end{tabular}




\begin{tabular}{|c|c|c|c|c|c|}
\hline $\begin{array}{c}\text { Spot } \\
\text { no. }\end{array}$ & Accession no. & Protein names & $\begin{array}{c}\text { Ratio of } \\
\text { 07-Cd/01-Cd }\end{array}$ & $\begin{array}{c}\text { Ratio of } \\
\text { 07-Cd/07-control }\end{array}$ & Anova \\
\hline 53 & SAI00778.1 & Elongation factor Tu & 1.3 & -1.8 & $3.38 \mathrm{E}-02$ \\
\hline
\end{tabular}

2 
Figure $\mathbf{1}$ (on next page)

Growth curves of E. cloacae strains ATCC 13047 (A), EC01 (B) and EC07 (C) in the absence (opened symbol) and presence (closed symbol) of $0.2 \mathrm{mM} \mathrm{CdCl}$. Optical density at $600 \mathrm{~nm}$ was monitored at 1-h intervals for $24 \mathrm{~h}$. 
A

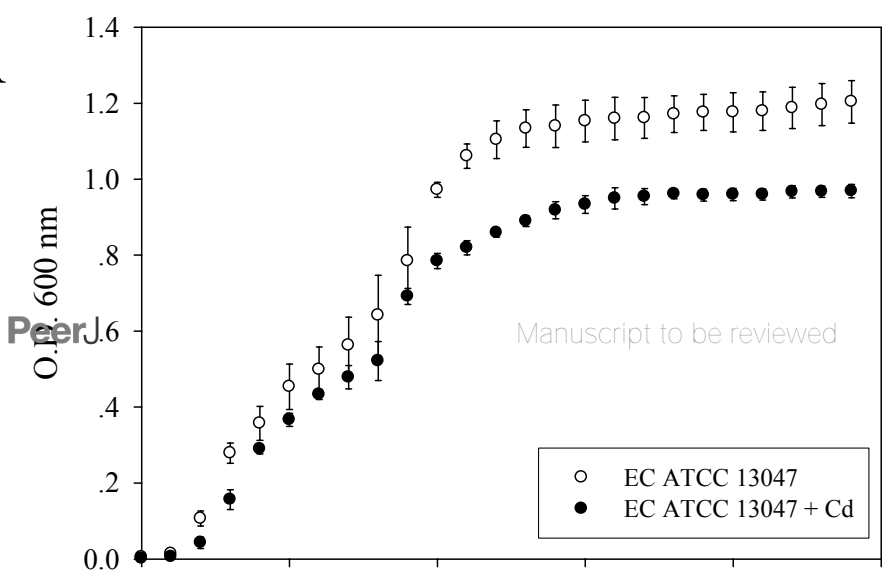

B

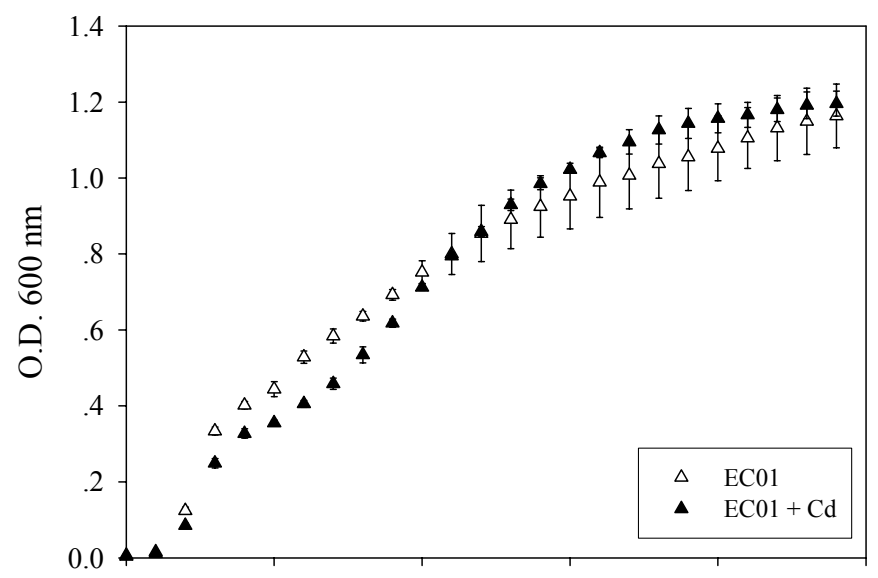

C

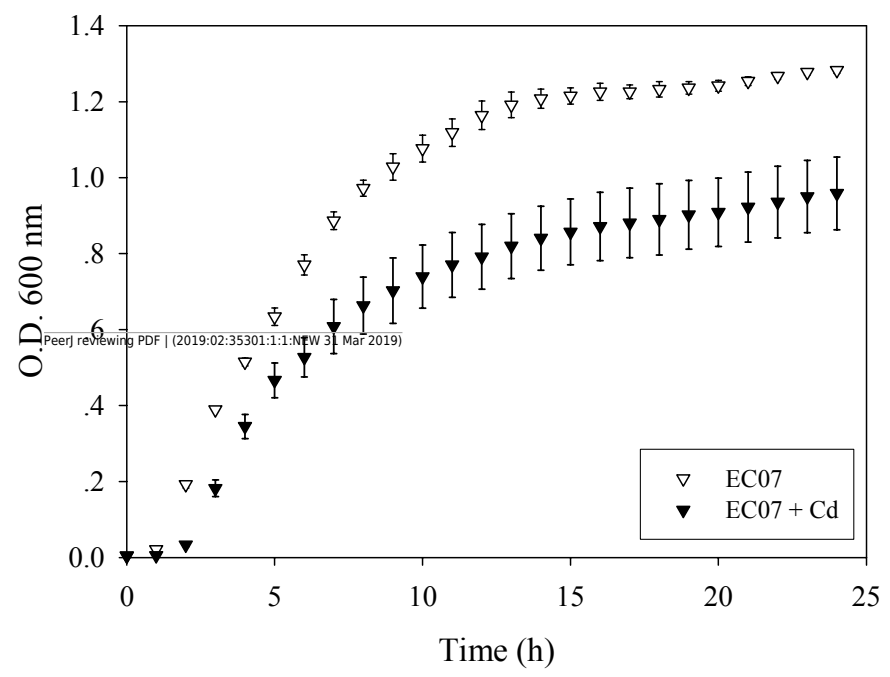


Figure 2 (on next page)

Time-course cadmium adsorption by E. cloacae tolerant strain (ECO1), intolerant strain (EC07) and ATCC strain grown in LB broth containing $0.2 \mathrm{mM} \mathrm{CdCl} 2$ at $37^{\circ} \mathrm{C}$. Error bars represent as mean \pm SD. 
Figure 3 (on next page)

Cadmium adsorptivity of whole cell proteins from E. cloacae tolerant strain (EC01), intolerant strain (EC07) and ATCC strain. Error bars represent as mean \pm SD. 


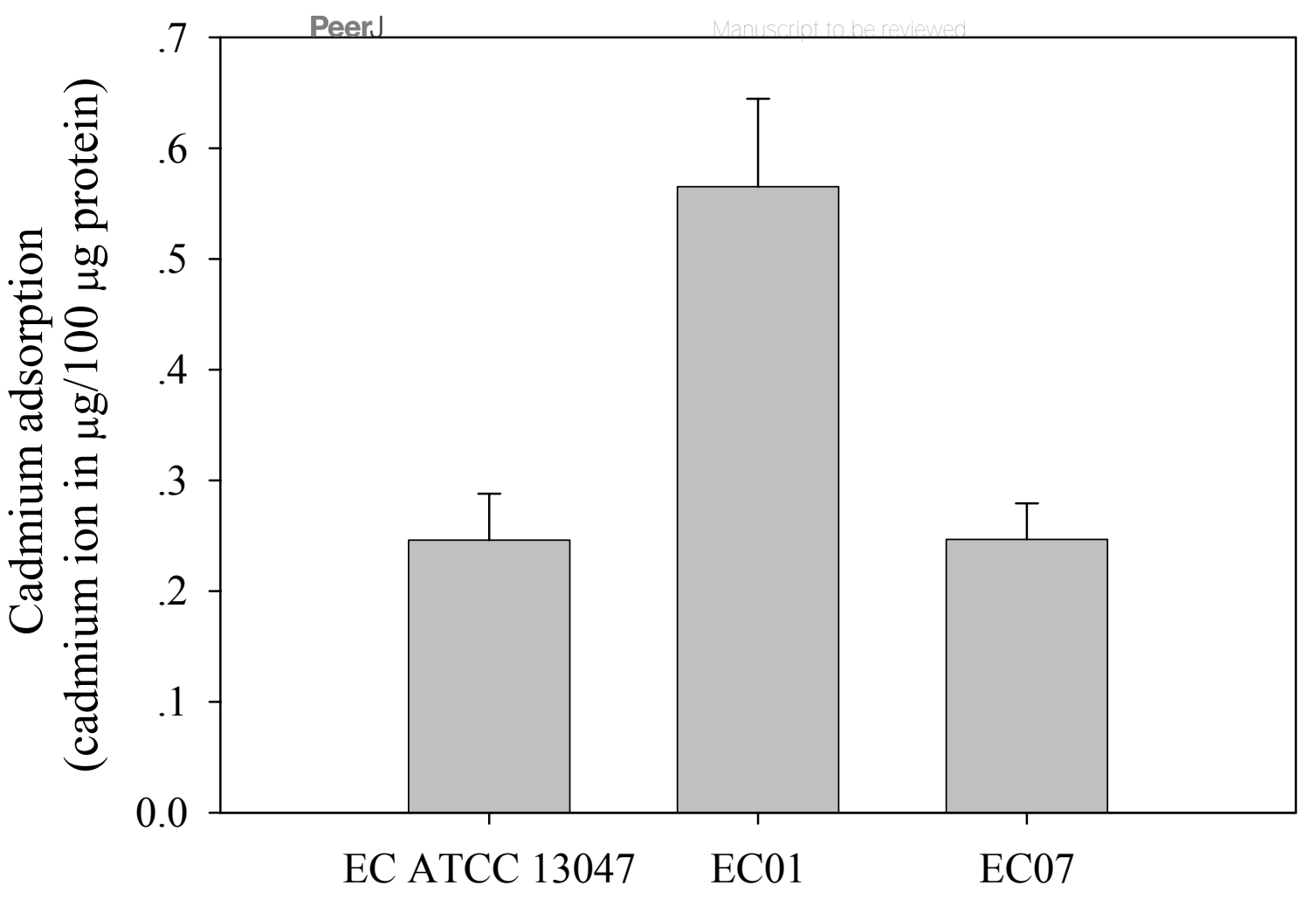

Proteins from different strains of Enterobacter cloacae 


\section{Figure 4}

2-DE image of $350 \mu \mathrm{g}$ of total soluble proteins extracted from E. cloacae ATCC 13047.

The proteins were immobilized on Immobiline Dry strips with nonlinear pH gradient from 3 to 10 followed by SDS-PAGE on $12.5 \%$ polyacrylamide gels. Protein spots were visualized by coomassie brilliant blue R-250 (CBB) staining. Eighty protein spots were identified as marked with arrows.

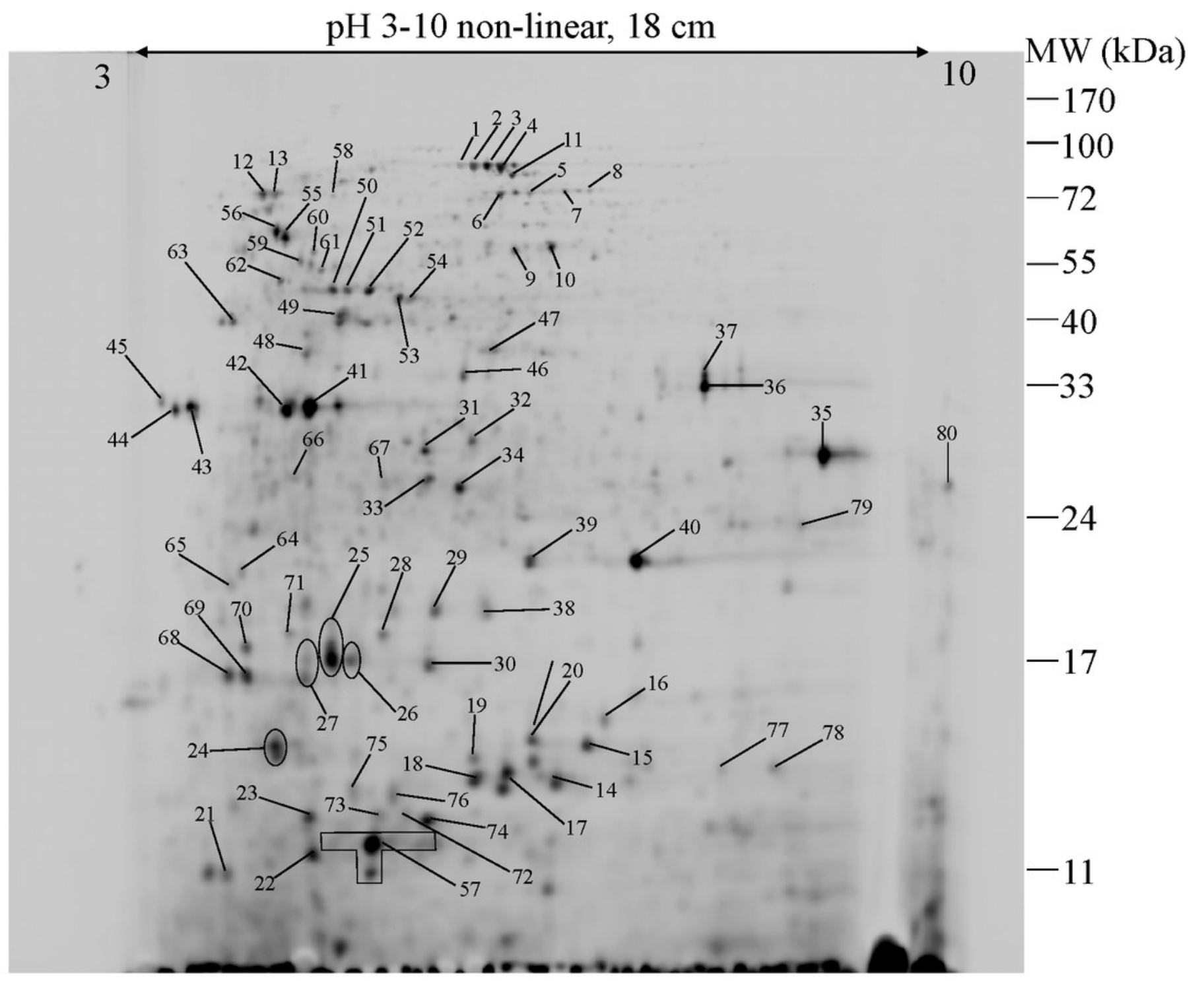


Figure $\mathbf{5}$ (on next page)

Numbers of proteins involved in various biological processes of E. cloacae ATCC 13047.

Functional analysis of proteins was identified by UniProtKB database. 
2p बerv

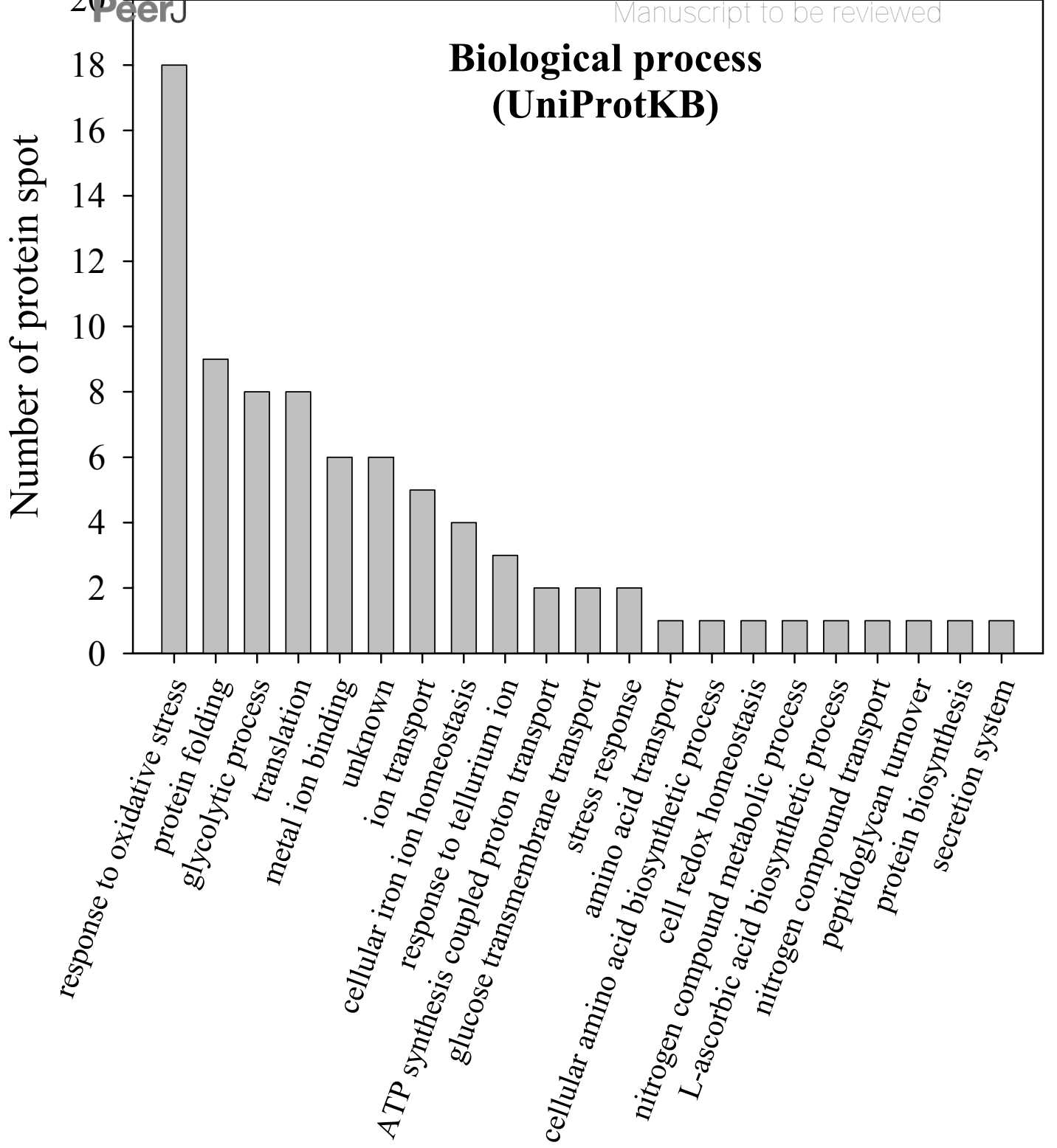




\section{Figure 6}

Venn diagram showing the number of significantly up-regulated proteins from 3 strains of $E$. cloacae with $P$-value $\leq 0.05$ and fold change $\geq 1.3$ under cadmium stress.

The diagram indicates the overlap between the tolerant (EC01), intolerant (EC07) and ATCC 13047 strains.

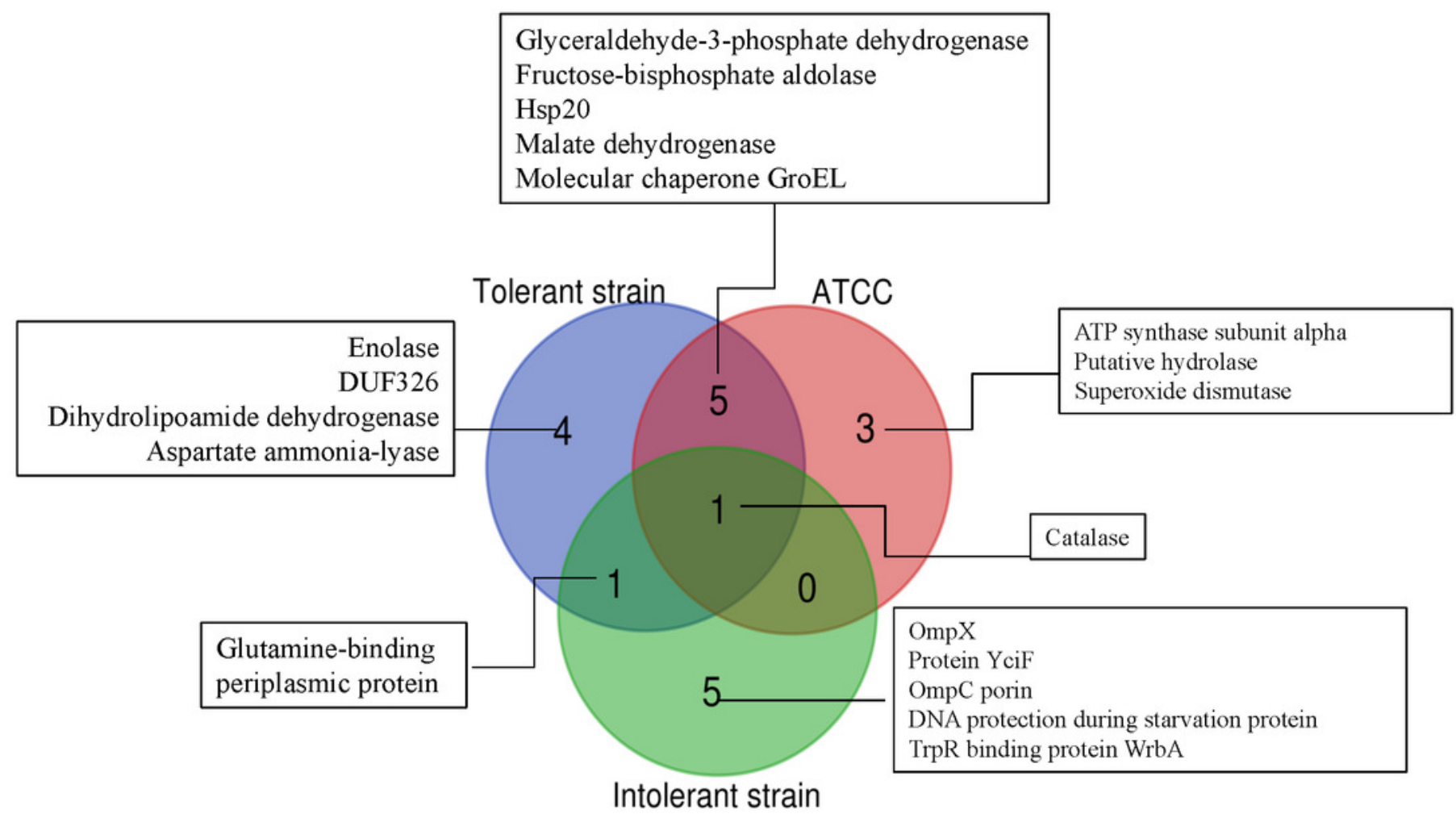


Figure 7 (on next page)

Fold differences in transcription level between DUF326 gene (target gene) and GAPDH gene (hoursekeeping gene) in E. cloacae strains EC01, EC07 and ATCC 13047 in the absence and presence of cadmium ions. 


\begin{tabular}{|c|c|c|c|c|c|c|c|c|}
\hline \multirow{2}{*}{ Condition } & \multicolumn{2}{|c|}{ DUF326 gene } & \multicolumn{2}{|c|}{ GAPDH gene } & \multirow{2}{*}{\multicolumn{2}{|c|}{$\begin{array}{cc}\Delta \mathbf{C q} & \Delta \mathbf{C q} \\
\text { control } & \text { cadmium }\end{array}$}} & \multirow{2}{*}{$\Delta \Delta \mathbf{C q}$} & \multirow{2}{*}{$\begin{array}{c}\text { Fold } \\
\text { difference }\end{array}$} \\
\hline & Mean & S.D. & Mean & S.D. & & & & \\
\hline $\begin{array}{l}\text { EC01 } \\
\text { control }\end{array}$ & 23.28 & 4.24 & 31.61 & 4.30 & -8.33 & - & -3.82 & 14.13 \\
\hline $\begin{array}{c}\text { EC01 } \\
\text { cadmium }\end{array}$ & 21.49 & 1.49 & 26.00 & 2.72 & - & -4.51 & & \\
\hline $\begin{array}{c}\text { EC07 } \\
\text { control }\end{array}$ & 32.57 & 1.87 & 34.88 & 2.36 & -2.31 & - & -0.35 & 1.28 \\
\hline $\begin{array}{c}\text { EC07 } \\
\text { cadmium }\end{array}$ & 31.16 & 1.53 & 33.11 & 1.71 & - & -1.96 & & \\
\hline $\begin{array}{l}\text { ATCC } \\
\text { control }\end{array}$ & 31.56 & 0.99 & 25.24 & 2.86 & 6.32 & - & -0.57 & 1.49 \\
\hline $\begin{array}{c}\text { ATCC } \\
\text { cadmium }\end{array}$ & 33.59 & 2.39 & 26.70 & 1.49 & - & 6.89 & & \\
\hline
\end{tabular}

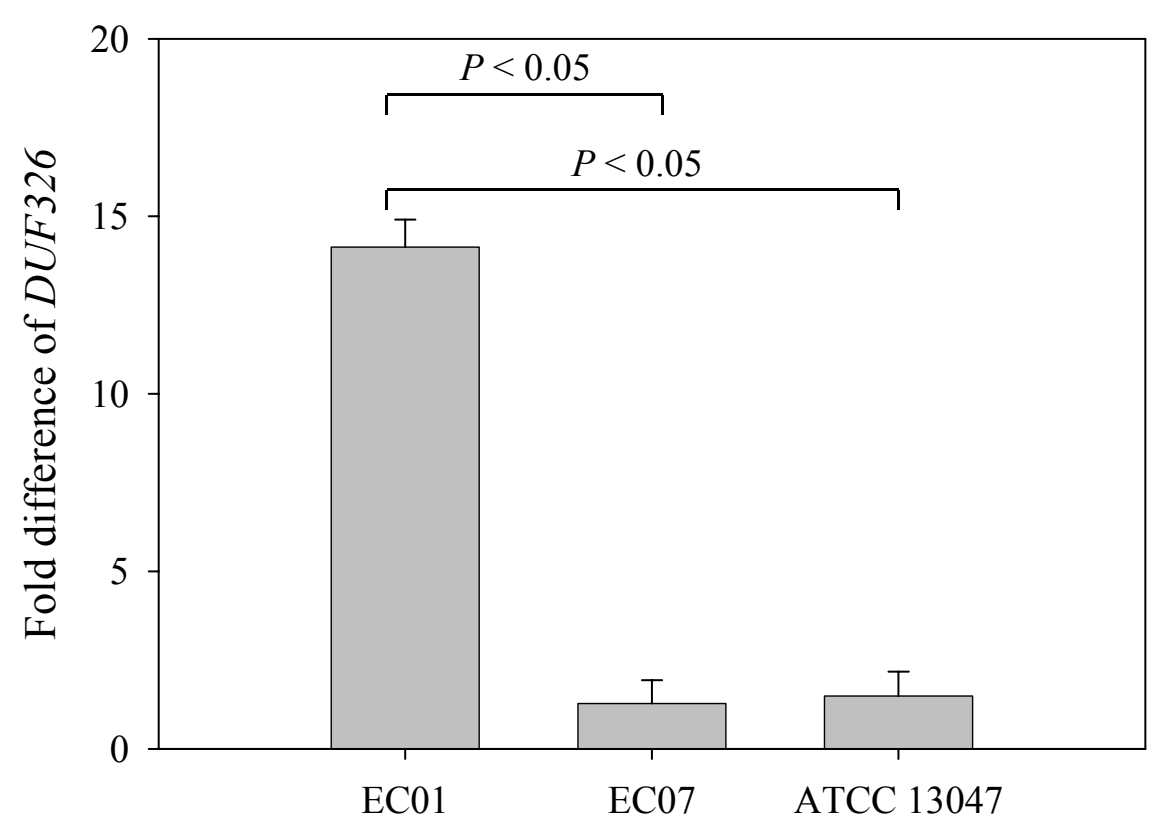

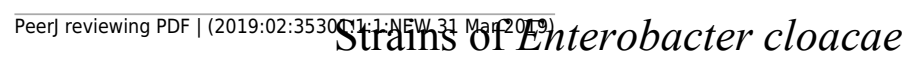




\section{Figure 8}

The superimposed of 2D-DIGE gels representing differentially expressed proteins of $E$. cloacae strains EC01 (A), EC07 (B) and ATCC 13047 (C) in the presence of cadmium ions at different locations (zoomed gels)

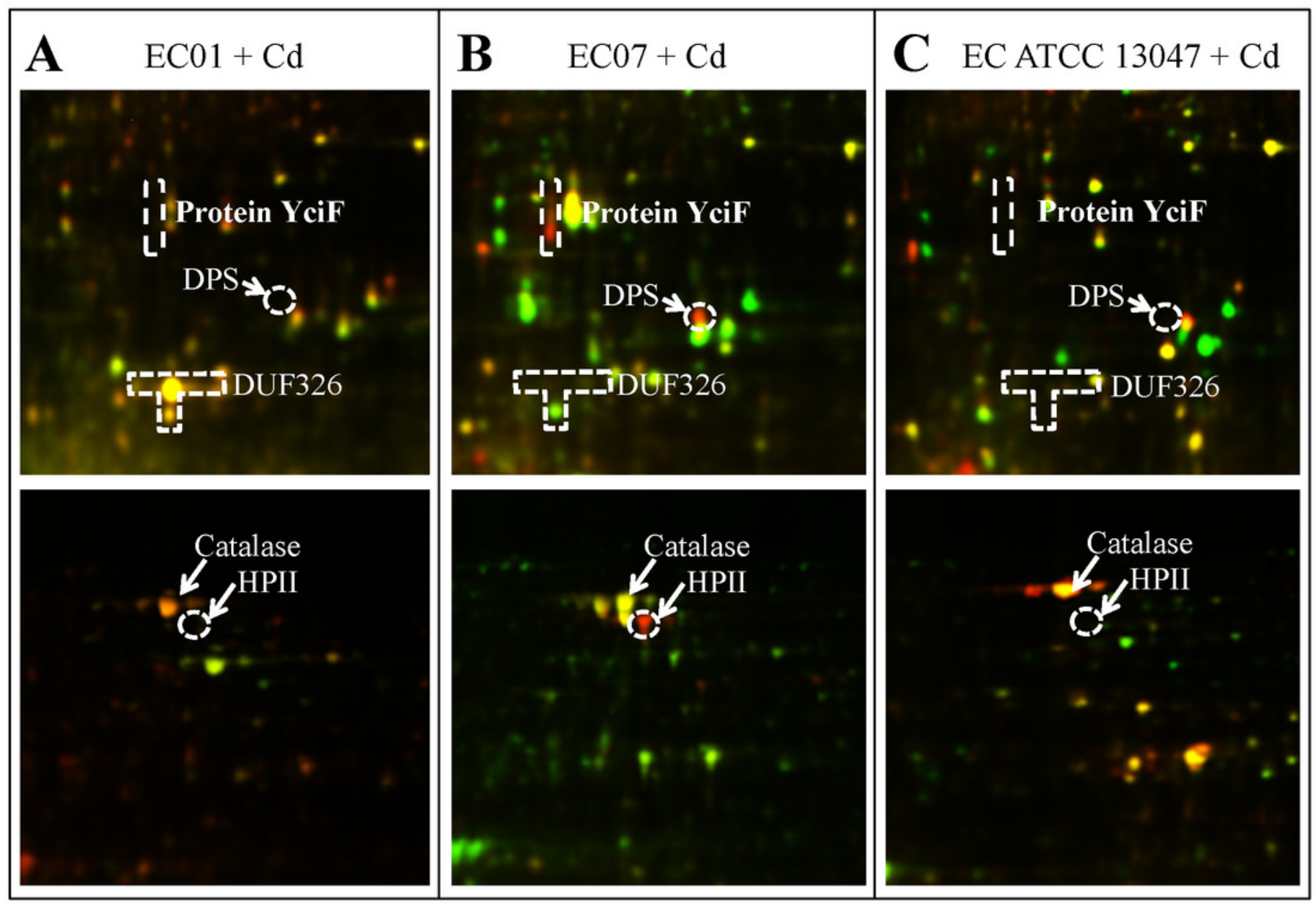


Figure 9

Amino acid sequences and the predicted tertiary structure of Domain of Uncharacterized Function (DUF326)

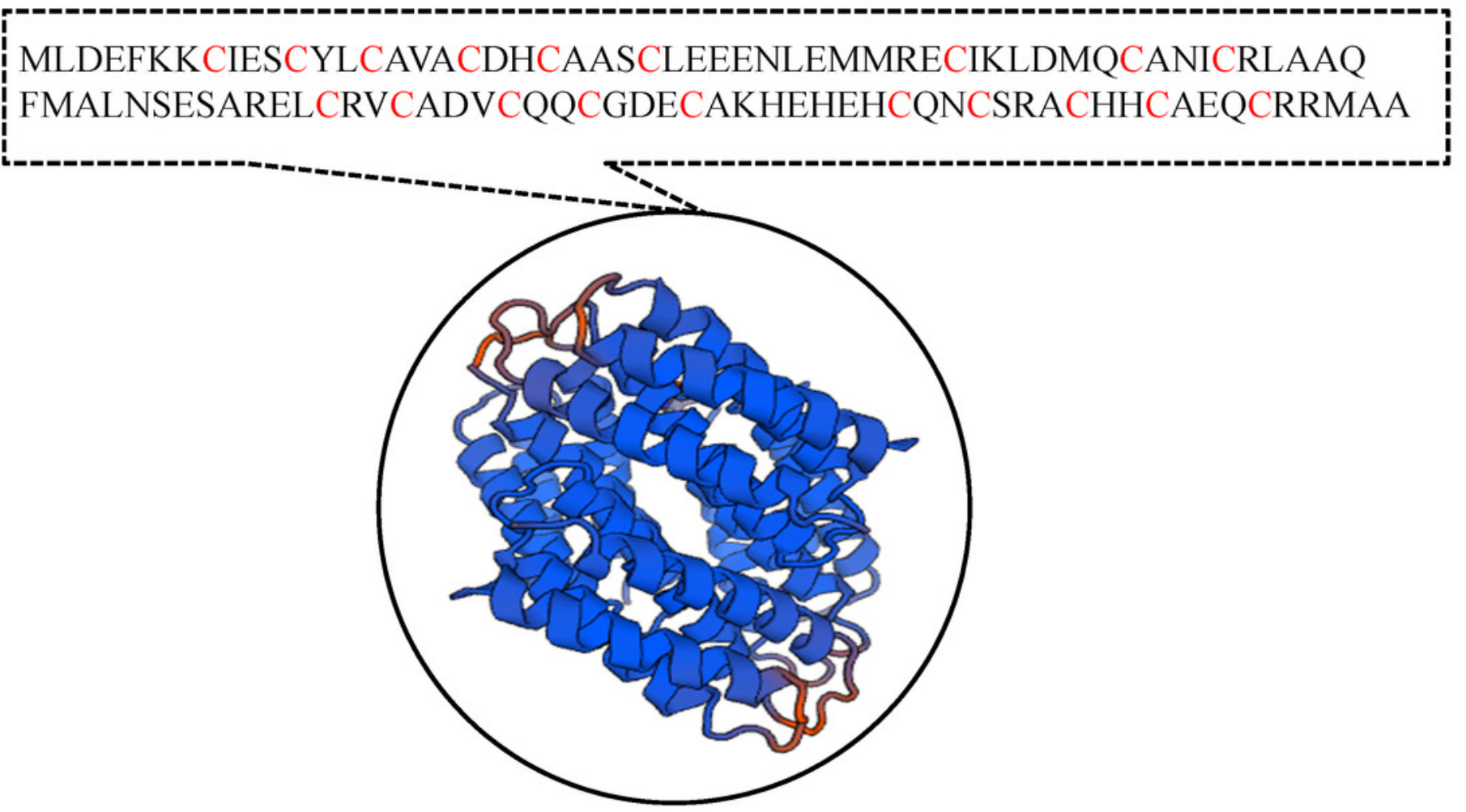




\section{Figure 10}

Relationship between genes encoding protein of hypothetical function DUF326 (from Sporosarcina newyorkensis) and other proteins as identified by the STRING software

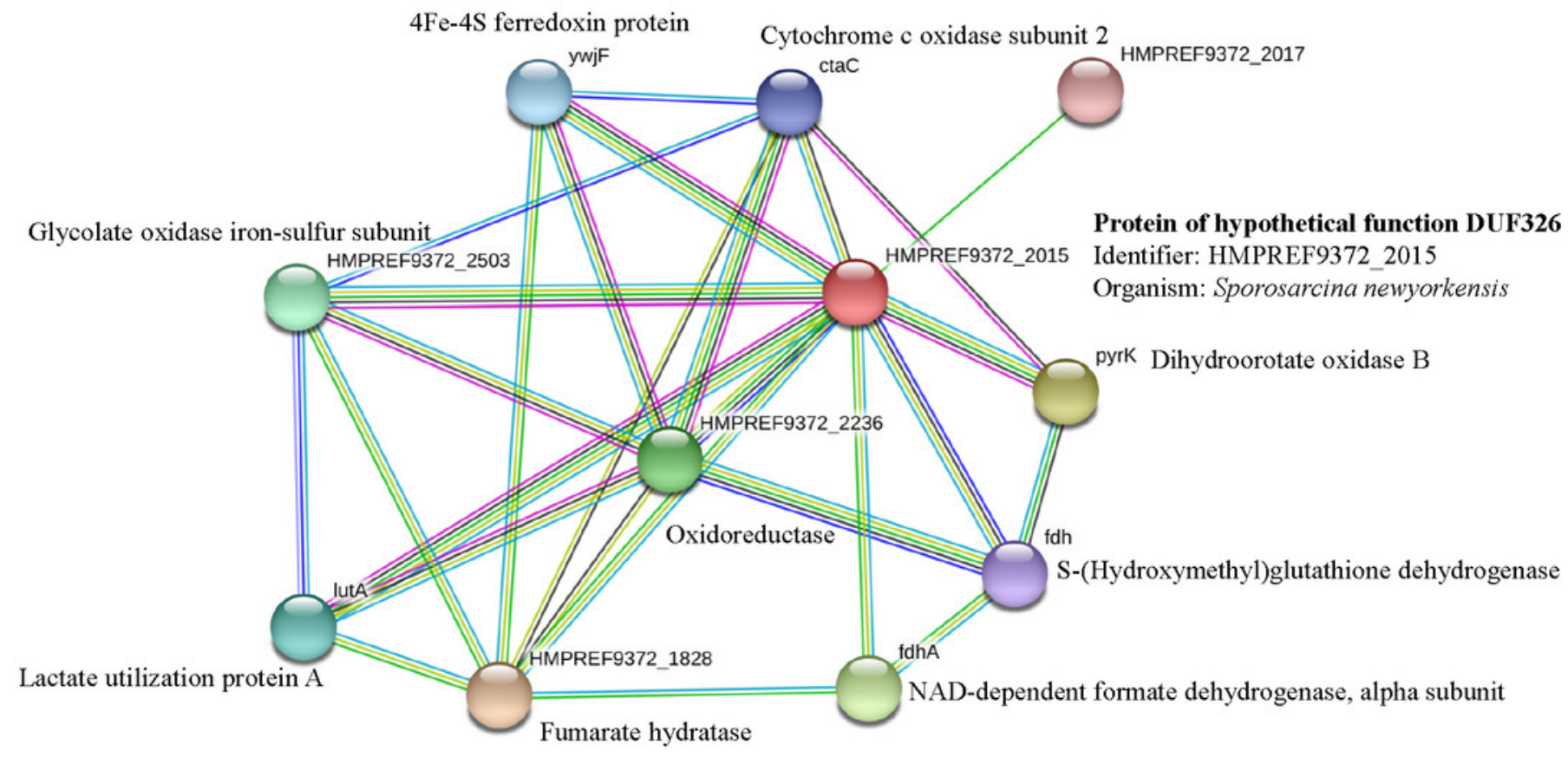


Figure 11

Relationship between genes encoding proteins of E. cloacae strains EC01, EC07 and ATCC 13047 involved in responses to cadmium stress as identified by the STRING software

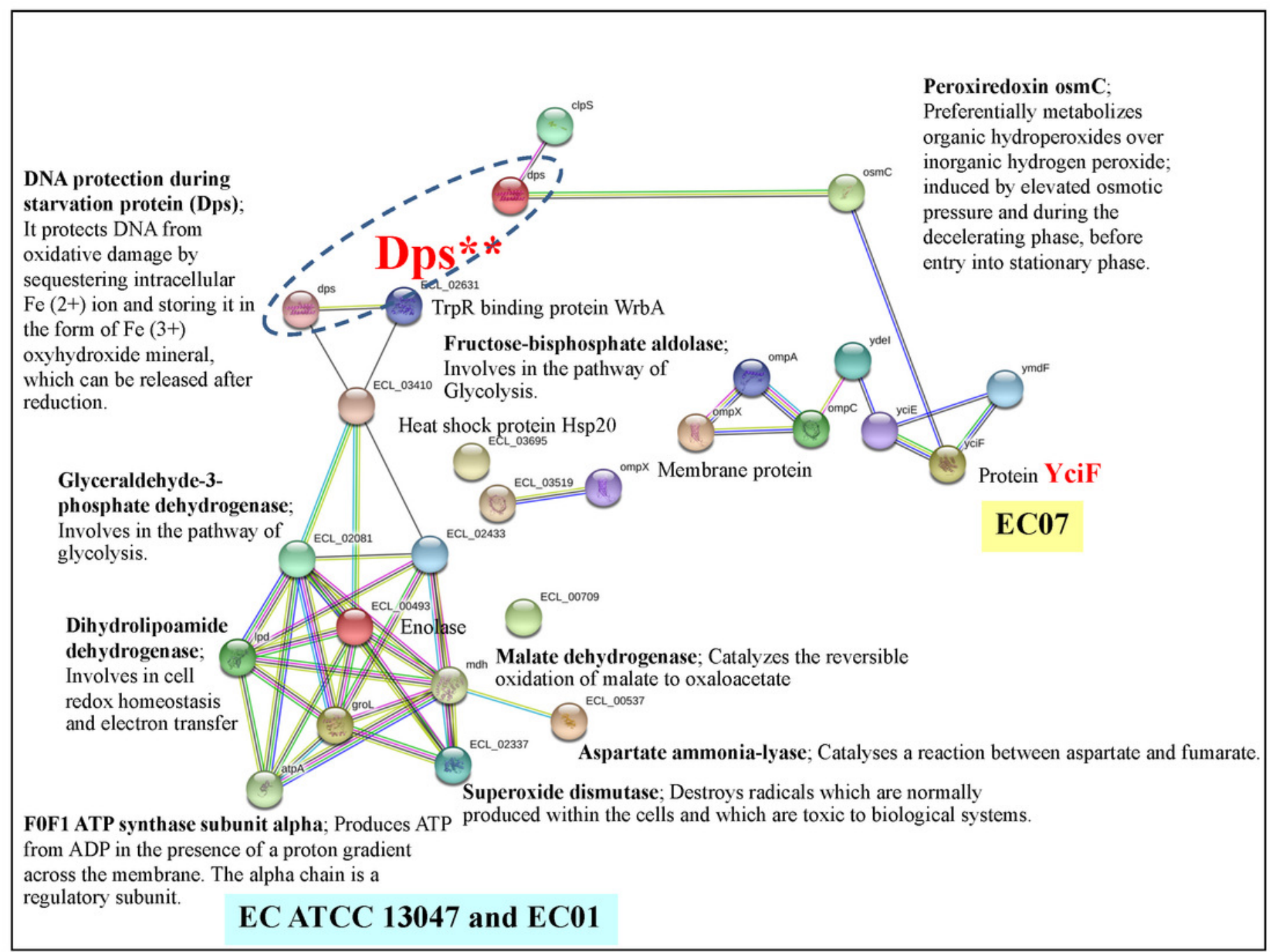

